\title{
Article \\ Protective Effect of Wheat and Barley Grass Against the Acute Toxicological Effects of the Concurrent Administration of Excessive Heavy Metals in Drinking Water on the Rats Liver and Brain
}

\author{
Hanan S.E. Eldamaty ${ }^{1}$, Heba Elbasiouny ${ }^{2, *(1)}$, Amira M. Elmoslemany ${ }^{1}$, Lamiaa M. Abd El-Maoula ${ }^{1}$, \\ Ola Ibrahim El-Desoky ${ }^{1}(\mathbb{D})$, Medhat Rehan ${ }^{3,4}{ }^{(\mathbb{D}}$, Diaa Abd El Moneim ${ }^{5}$ (D) and Amina Zedan ${ }^{2}$ (D)
}

1 Nutrition and Food Science Department, Faculty of Home Economics, Al-Azhar University, Tanta 31732, Egypt; hananeldamaty@azhar.edu.eg (H.S.E.E.); amiraelmoslemany@azhar.edu.eg (A.M.E.); dr_lamiaamostafa@azhar.edu.eg (L.M.A.E.-M.); olael-desoky@azhar.edu.eg (O.I.E.-D.)

2 Department of Environmental and Biological Sciences, Home Economy Faculty, Al-Azhar University, Tanta 31732, Egypt; AminaZedan1948.el@azhar.edu.eg

3 Department of Genetics, Faculty of Agriculture, Kafrelsheikh University, Kafr El-Sheikh 33516, Egypt; medhat.rehan@agr.kfs.edu.eg

4 Department of Plant Production and Protection, College of Agriculture and Vterinary Medicine, Qassim University, Burydah 51452, Saudi Arabia

check for updates

Citation: Eldamaty, H.S.E.;

Elbasiouny, H.; Elmoslemany, A.M.; Abd El-Maoula, L.M.; El-Desoky, O.I.; Rehan, M.; Abd El Moneim, D.;

Zedan, A. Protective Effect of Wheat and Barley Grass Against the Acute Toxicological Effects of the

Concurrent Administration of Excessive Heavy Metals in Drinking Water on the Rats Liver and Brain. Appl. Sci. 2021, 11, 5059. https:// doi.org/10.3390/app11115059

Academic Editor: Francisco Arrebola

Received: 2 May 2021

Accepted: 28 May 2021

Published: 30 May 2021

Publisher's Note: MDPI stays neutral with regard to jurisdictional claims in published maps and institutional affiliations.

Copyright: (c) 2021 by the authors. Licensee MDPI, Basel, Switzerland. This article is an open access article distributed under the terms and conditions of the Creative Commons Attribution (CC BY) license (https:// creativecommons.org/licenses/by/ $4.0 /)$.
5 Department of Plant Production (Genetic Branch), Faculty of Environmental and Agricultural Sciences, Arish University, El-Arish 45511, Egypt; dabdelmoniem@Aru.edu.eg

* Correspondence: Hebaelbasiouny@azhar.edu.eg

Abstract: Heavy metal contaminated water is a great concern because of its high toxiciy, nonbiodegradability, and bioaccumulation. Therefore, non-contaminated water is fundamental for a healthy life. Special attention is paid to the health-promoting ingredients of germinated whole cereal products. This study aimed to (1) examine the potentially harmful effects of $\mathrm{Cu}, \mathrm{Mn}$, and $\mathrm{Zn}$ on rat livers and brains, and (2) the potentially protective action of wheat and barley grasses against the expected harmful effects of these metals. The rats were treated with water contaminated by heavy metals (HMs) and germinated wheat and barley for 60 days. The rat liver functions and histopathological examinations were analyzed. Comet assay was evaluated to assess the damage in the DNA of rat livers and brains. The results indicated a significant alteration in liver functions in rats exposed to HMs; however, wheat and barley grasses at high doses decreased the harmful effects. An insignificant difference was noticed in total protein, albumin, and globulin of rats treated with HMs compared with the control. A significant increase in the serum and liver levels of HMs was recorded; however, they were reduced by wheat and barley grasses. Rat livers treated with HMs exhibited severe histological effects. The groups treated with wheat and barley grasses showed a normal liver architecture. A significant increase in DNA damage in the livers and brains was observed in rats treated with HMs, which was reduced when treated with wheat and barley grasses. Thus, using germinated seeds is promising to avoid damaging of HMs.

Keywords: drinking water contamination; heavy metals; rat liver; rat brain; germinated wheat; germinated barley; protective action

\section{Introduction}

It is well-recognized that clean and high-quality water is certainly fundamental for the health of all livings. It has been globally observed that millions of people are divested of this, and approximately $80 \%$ of all human diseases in developing nations are correlated to contaminated water, which leads to an increased number of deaths worldwide. This can lead to more than 14,000 deaths daily [1]. Chronic diseases such as liver cirrhosis occur because of the contamination of drinking water by heavy metals (HMs) such as $\mathrm{Cu}, \mathrm{Cd}$, 
$\mathrm{Ni}, \mathrm{Cr}$, and $\mathrm{Pb}$ [2]. During the past few decades, urbanization and rapid industrialization have increasingly contaminated the environment with HMs in many countries [3,4]. Heavy metals can be released into the environment either naturally or anthropogenically [1,3-7]. $\mathrm{HM}$ contamination, unlike organic contamination, is of great interest because of its high toxicity, concealment, persistence, enrichment, non-degradability, and bioaccumulation in higher trophic levels [4,6,8-10]. However, some $\mathrm{HMs}$ (such as $\mathrm{Cr}, \mathrm{Cu}, \mathrm{Fe}, \mathrm{Mn}, \mathrm{Ni}$, and $\mathrm{Zn}$ ) are essential and are needed in small quantities for living organisms because they perform an important role in the metabolism of the human body, with small limits from deficit to toxicity. However, the excessive concentrations of these metals may be toxic $[3,6,11]$. The intake of contaminated food and water is the most important pathway of human exposure to HMs. HMs tend to accumulate in many organs and cause potential health hazards including intracellular accumulated redox-active metals (such as $\mathrm{Co}, \mathrm{Cr}, \mathrm{Cu}$, and $\mathrm{Fe}$ ), which catalyze free-radical reactions and disturb the chain of electron transport in the mitochondria, causing the unceasing generation of reactive oxygen species (ROS). This disturbance causes oxidative stress, which then prompts DNA damage, protein modification, and lipid peroxidation [9].

Among $\mathrm{HMs}, \mathrm{Cu}$ is one of the essential nutrients and biosyntheses that aids in maintaining normal biochemical and physiological tasks in plants, animals, and humans. However, $\mathrm{Cu}$ is toxic at high concentrations $[10,12,13]$. The most widespread source of $\mathrm{Cu}$ in drinking water is the corrosive action of water leaching $\mathrm{Cu}$ pipes in buildings due to increased levels of dissolved oxygen. The health-based standard value of $\mathrm{Cu}$ is $2 \mathrm{mg} \mathrm{L}^{-1}$ [14]. Zinc is also an essential nutrient in almost all food and drinkable water. It acts as a cofactor of various catalytic enzymes in living cells. In addition, it is a vital nutrient that participates in cell division. It performs functions in the growth and development of organs, particularly in pregnant women and infants [14-16]. Together with $\mathrm{Cu}, \mathrm{Zn}$ contributes to the mechanisms of antioxidative stress [16]. The dissolution of $\mathrm{Zn}$ from pipes is the highest source for a high concentration of $\mathrm{Zn}$. The health-based standard value of $\mathrm{Zn}$ is $3 \mathrm{mg} \mathrm{L}^{-1}$ and the concentrations higher than this are not acceptable for human use [14,17]. In addition, $\mathrm{Mn}$ is a vital metal to human health that acts as a co-factor in the activity of many enzymes. It is needed in order to maintain the functions of the nerve systems and immune cells, as well as for normal development and for regulating the blood sugar and vitamin levels. However, overexposure to Mn can also be toxic to many organs [18]. The main source of $\mathrm{Mn}$ is coating on pipes. An Mn concentration below $0.1 \mathrm{mg} \mathrm{L}^{-1}$ is usually acceptable to humans $[14,17]$.

Germinated wheat (Triticum aestivum) seeds are new high value-added products that have been presented to the food market as a result of their high nutritional value and their potential to enhance the nutrient uptake, in addition to flavour and taste [19]. Wheat is a major global crop and is a prime source of biologically active substances. It has antioxidative, anti-inflammatory, anticancer, and anti-obesity effects. It is reported that polysaccharides derived from germinated wheat and various biological sources protect against hepatic injury and fibrosis as a result of their antioxidative and anti-inflammatory effects $[20,21]$. The antioxidant activity of wheat and barley grasses at various protection degrees has been well investigated. They contain many antioxidant vitamins, for example, A, B, C, and E; the antioxidant content of chlorophyll; and antioxidant enzymes, such as SOD, cytochrome oxidase, and some other enzymes [22,23]. Barley (Hordeum vulgare L.) is one of the very important annual crops, following wheat, rice, and corn. It often serves as an essential ingredient in processed foods like bakery, brewing, and malted products. In addition, it is increasingly considered a healthy food as a result of its high contents of minerals, vitamins, bioactive carbohydrates and polyphenols, flavonoids, polypeptide, $\beta$-glucan, arabinoxylans, and phenolic compounds [24,25].

Many researchers have examined the proactive effect of wheat and barley grasses (either juice, extract, milted, or even germinated) on liver function and injury as a result of alcohol exposure or other reasons [22-28]. However, no information is available regarding their protective influence after germination against toxic metals on the liver. This study 
aims to study the potentially harmful effects of excess $\mathrm{HMs}$ (i.e., $\mathrm{Cu}, \mathrm{Mn}$, and $\mathrm{Zn}$ ) on rats livers and brains. In addition, the novelty of this study is to examine the potentially protective effect of germinated wheat and barley against the expected damaging effect of concurrent exposure to $\mathrm{Cu}, \mathrm{Zn}$, and $\mathrm{Mn}$ on liver functions, biological marks, hepatic injury, and liver DNA damage. These metals were selected because their levels were the highest in the study area.

\section{Materials and Methods}

\subsection{Pre-Survey Study}

This section is designed to recognize the most concentrated HMs in the drinking water and the nearby drainage water to be used in the experiment. Firstly, five samples (1-5) were collected; the first sample was collected from the drain that received the discharge from a factory of dyed clothes, and the other four samples (from 2-5) were collected from tap water from houses adjacent to the clothes dye factory in the Northern Nile Delta, Egypt $\left(30^{\circ} 45^{\prime} 40^{\prime \prime} \mathrm{N}, 31^{\circ} 06^{\prime} 53^{\prime \prime} \mathrm{E}\right)$. The samples were analyzed for $\mathrm{Cu}, \mathrm{Mn}, \mathrm{Ni}, \mathrm{Pb}, \mathrm{Cd}$, and $\mathrm{Zn}$. The metal values were higher in $\mathrm{Cu}, \mathrm{Mn}$, and $\mathrm{Zn}$, but they were non-detected or not sensible for other metals (Table 1). The low detection limits (LODs) of $\mathrm{Cd}, \mathrm{Ni}$, and $\mathrm{Pb}$ were 0.015 , 0.035 , and, 0.045 respectively. The samples were collected as follows:

(1) A sample from an outlet drain of a clothes dye factory;

(2) A sample from a pump $60 \mathrm{~m}$ from the drain, with a pump depth of $42 \mathrm{~m}$;

(3) A sample from a pump $200 \mathrm{~m}$ away from the factory;

(4) A sample from a house $500 \mathrm{~m}$ away from the factory;

(5) A sample from a house $1 \mathrm{~km}$ away from the factory.

Table 1. The concentrations of $\mathrm{Cu}, \mathrm{Mn}$, and $\mathrm{Zn}\left(\mathrm{mg} \mathrm{L}^{-1}\right)$ in the drinking water samples from the study area.

\begin{tabular}{cccc}
\hline Sample Number & $\mathbf{C u}$ & Mn & Zn \\
\hline $\mathbf{1}$ & 1.63 & 7.15 & 5.07 \\
$\mathbf{2}$ & $\mathrm{nd}^{*}$ & 0.56 & 0.88 \\
$\mathbf{3}$ & 0.12 & 0.32 & 0.64 \\
$\mathbf{4}$ & 0.06 & 0.90 & 0.95 \\
$\mathbf{5}$ & 0.05 & 0.32 & 0.72 \\
$\mathbf{6}$ & 1.50 & 2.08 & 4.38 \\
$\mathbf{7}$ & 1.15 & 0.58 & 2.45 \\
$\mathbf{8}$ & 1.03 & 0.85 & 4.48 \\
$\mathbf{9}$ & 0.73 & 0.30 & 1.68 \\
$\mathbf{1 0}$ & 0.73 & 0.70 & 3.35 \\
$\mathbf{1 1}$ & 0.55 & 0.68 & 2.33 \\
$\mathbf{1 2}$ & 0.78 & 0.95 & 3.25 \\
$\mathbf{1 3}$ & 0.78 & 0.28 & 3.00 \\
$\mathbf{1 4}$ & 0.20 & 0.53 & 3.30 \\
$\mathbf{1 5}$ & 0.15 & 4.55 & 1.83 \\
Permissible Limits of WHO (2011) & 2.0 & 0.4 & 3.0 \\
Permissible Limits of EMH (2011) & 2.0 & 0.4 & 3.0 \\
\hline
\end{tabular}

*nd: non-detected.

Ten other samples (from 6-15) were collected from houses at different distances, and a variation was found in their results. However, Mn was higher than the permissible limits of drinking water $[14,29]$ in eight samples, $\mathrm{Zn}$ values were higher in four samples, and $\mathrm{Cu}$ was lower than those limits (although $\mathrm{Cu}$ was higher than the other examined metals) (Table 1). The samples were collected as follows:

(1) A sample from the water station treatment before treatment and after about $3 \mathrm{~km}$ from the water intake from the Nile;

(2) A sample from the water station after treatment;

(3) A sample from a house $200 \mathrm{~m}$ away from the station; 
(4) A sample from a house $400 \mathrm{~m}$ away from the station;

(5) A sample from a house $600 \mathrm{~m}$ away from the station;

(6) A sample from a house $800 \mathrm{~m}$ away from the station;

(7) A sample from a house $1000 \mathrm{~m}$ away from the station;

(8) A sample of a house $1200 \mathrm{~m}$ away from the station;

(9) A sample from a house $1400 \mathrm{~m}$ away from the station;

(10) A sample from a house $1600 \mathrm{~m}$ away from the station.

\section{Heavy Metals Analysis}

Two-litres of water samples were collected in triplicate and were filtered. One of them was acidified by $\mathrm{HNO}_{3}(2 \%)$ and was concentrated at $64{ }^{\circ} \mathrm{C}$ into $50 \mathrm{~mL}$ for metals analysis using Graphite Furnace-Atomic Absorption Spectrometry (GBC Avanta E, Victoria, Australia) [30]. According to the results, the most concentrated metals were $\mathrm{Cu}, \mathrm{Mn}$, and $\mathrm{Zn}$, and so they are the only ones mentioned in Table 1.

\subsection{Plants Germination and Composition}

The barley and wheat grains were obtained from the Agricultural Research Center, Sakha, Kafr Elsheikh, Egypt. Barley and wheat grains were soaked overnight in water and the next day they were spread on plastic trays filled with soil. The grains were grown under indoor conditions. After the ninth day, grasses were harvested and chopped with a knife. They were dried in the shade and were ground with a mechanical grinder. The powder was passed through sieve no. 40 and was stored in a labelled airtight container until the rats' subjecting [31,32].

The chemical composition of both germinated plants (i.e., crude protein, crude fat, crude fibre, ash, and carbohydrate) was estimated [33]. Bioactive compounds by GC/MS System (Thermo Scientific TRACE 1310 Gas Chromatograph, Waltham, MA, USA) attached with an ISQ LT single quadrupole mass spectrometer.

\subsection{Animals and Experimental Design}

Thirty-five male albino rats of Sprague Dawley strain, with weights ranging from 150 to $200 \mathrm{~g}$ were acquired from the experimental animal house, Food Technology Research Institute, Agric. Res. Center, Giza, Egypt, and transported to the animal house of the Home Economic Faculty, Al-Azhar University, Egypt. After a 5 days acclimation period, the rats were randomly distributed into three main groups (the first and second groups had five rates in each group, while the third group had 25 rats). The first group (G1) was nourished on a basal diet and was administered distilled water orally for 60 days and was kept as a normal control (negative control). The second group (G2) was nourished on a basal diet and tap water (from sample number 6 as it was higher metal concentrations) orally for 60 days, and was kept as a group 1 (positive controlThe third group was fed a basal diet and mixed chemical minerals ( $\mathrm{Zn}\left(60 \mathrm{mg} \mathrm{L}^{-1}\right), \mathrm{Cu}\left(40 \mathrm{mg} \mathrm{L}^{-1}\right)$, and $\left.\mathrm{Mn}\left(20 \mathrm{mg} \mathrm{L}^{-1}\right)\right)$ to induce toxicity with HMs in male rats and werekept as group 2 (positive control). The metals were prepared with $\mathrm{ZnO}, \mathrm{CuO}$, and $\mathrm{MnO}_{2}$ from Sigma-Aldrich (St. Louis, MO, USA) and with distilled water. The rats in this group were divided into five subgroups (each group consisted of five rats), i.e., G3-1, G3-2, G3-3, G3-4, and G3-5, and were subjected to prepared drinking water (distilled water + mixed metals with the previous concentrations):

(1) G3-1: Subjected to prepared drinking water;

(2) G3-2: Subjected to prepared drinking water + wheatgrass $\left(250 \mathrm{mg} \mathrm{kg}^{-1} \mathrm{day}^{-1}\right)$;

(3) G3-3: Subjected to prepared drinking water + wheatgrass (500 $\left.\mathrm{mg} \mathrm{kg}^{-1} \mathrm{day}^{-1}\right)$;

(4) G3-4: Subjected to prepared drinking water + barley grass $\left(250 \mathrm{mg} \mathrm{kg}^{-1} \mathrm{day}^{-1}\right)$;

(5) G3-5: Subjected to prepared drinking water + barley grass $\left(500 \mathrm{mg} \mathrm{kg}^{-1} \mathrm{day}^{-1}\right)$ as in Figure 1. 


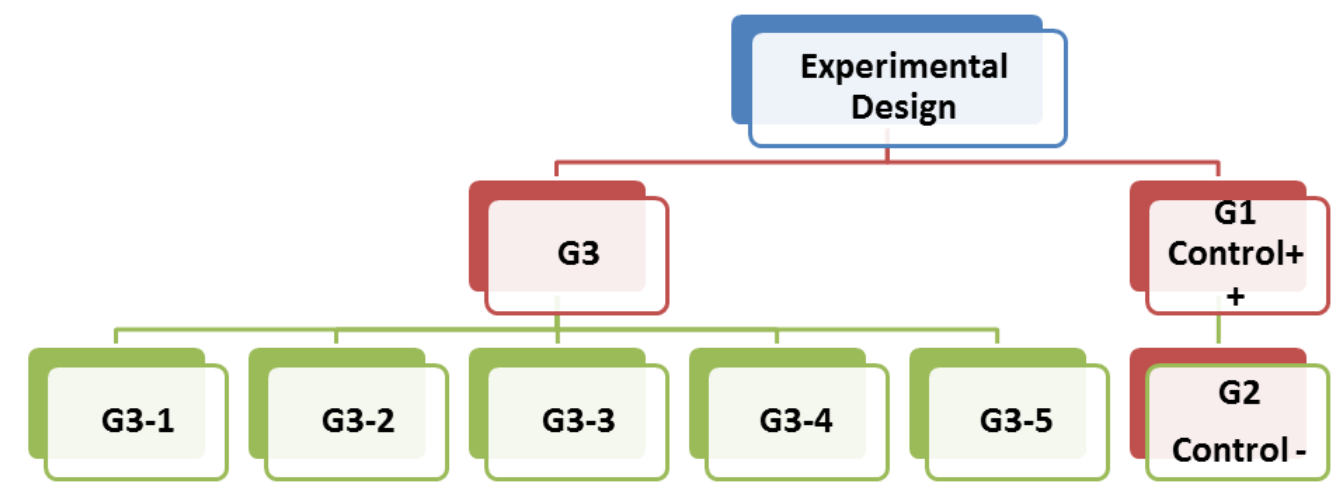

Figure 1. Treated groups in this study.

The rats received wheat and barley grasses, which were prepared freshly from the previous ground grasses, suspended in distilled water, and taken orally [34] during the experiment period (i.e., 60 days). Through the experiment period of 60 days, the rats were checked daily for general health and for the development of any physical anomalies. Twenty-four-hours after the last day of treatments, the rats in all groups were sacrificed. Liver and blood samples were directly collected for analysis. The experimental animals and procedures were handled according to the Institutional Aquatic Animal Care and Use Committee, Faculty of Aquatic and Fisheries Sciences, Kafrelsheikh University, Egypt.

\subsubsection{Biochemical Analyses of Examined Rats}

The biochemical parameters (each parameter was measured six times and the data were presented as a mean \pm standard deviation (SD)) were determined (aspartate aminotransferase (AST) and alanine aminotransferase (ALT) [35], serum alkaline phosphatase was assessed [36], serum total, direct and indirect bilirubin [37], total protein [38], and albumin and globulin [39]), and the albumin to globulin ratio (A/G) was estimated by dividing the A/G values, the serum TC [40], the serum HDL-C [41], and serum triglyceride [42]. The VLDL-C was estimated by dividing the serum triglyceride by 5, while the serum LDL-C was determined using the Friedewald formula [43]:

$$
(\mathrm{LDL}-\mathrm{C})=(\mathrm{TC})-(\mathrm{HDL}-\mathrm{C})-(\mathrm{TG} / 5)
$$

\subsubsection{Histopathological Examination of Liver}

Small parts of the liver were fixed in a $10 \%$ formalin solution. They were dehydrated in ethanol from $70-100 \%$, cleared in xylene, and embedded in paraffin. The liver sections were stained with Eosin and Hematoxylin dyes [44].

\subsubsection{Antioxidants Levels and Oxidative Markers in Liver Tissues}

The activities of CAT and GPx were assayed using biodiagnostic kits [45,46]. The MDA was estimated [47] and the NO was measured as nitrite and was determined in tissue homogenates [48] using ELISA (microplate reader Ryto2100 C, China).

\subsubsection{Determination of Acetylcholinesterase (ACHE) Activity in the Brain}

The ACHE activity was determined through the hydrolysis of acetylthiocholine. The incubation mixture of $1 \mathrm{~mL}$ contained $50 \mathrm{mM}$ of Tris- $\mathrm{HCl}$ with $\mathrm{pH} 8,120 \mathrm{mM} \mathrm{NaCl}, 240 \mathrm{mM}$ sucrose, and a protein concentration of $80-100 \mu \mathrm{g} \mathrm{mL}^{-1}$. The reaction was started after adding $0.03 \mathrm{~mL}$ of $5,5^{\prime}$-dithionitrobenzoic acid (DTNB) and $0.05 \mathrm{~mL}$ of acetylthiocholine iodide, which were used as the substrate. The final DTNB concentrations and substrate were 0.125 and $0.5 \mathrm{mM}$, respectively. The reaction was measured spectrophotometrically at an absorbance of $412 \mathrm{~nm}$ [49] (by spectrophotometer T80+ UV/VIS, Leicester, UK). 


\subsubsection{Comet Assay (Antimutagenic Test)}

The Comet aassay was used to assess the quantitative and qualitative extent of DNA damage by estimating the DNA migration length and the percentage of migrated DNA. Briefly, $1 \mathrm{~g}$ of crushed sample was transmitted to $1 \mathrm{~mL}$ ice-cold PBS. The suspension was stirred for $5 \mathrm{~min}$ and was then filtered. A volume $100 \mu \mathrm{L}$ of cell suspension was integrated with $600 \mu \mathrm{L}$ of agarose (low-melting, $0.8 \%$ in PBS), then $100 \mu \mathrm{L}$ of the mixture was dispersed on slides that were submerged in a lysis buffer $((\mathrm{NaCl}(2.5 \mathrm{M})$; EDTA $(100 \mathrm{mM})$; TRIS $(10 \mathrm{mM})$; Lauryl sarcosinate (1\% v); Triton-X-100 (1\% v), and DMSO (10\% v)) for $15 \mathrm{~min}$. The slides were put into an electrophoresis chamber that contained the same lysis buffer without SDS. The electrophoresis was run at $100 \mathrm{~mA}$ and $2 \mathrm{~V} / \mathrm{cm}$ for $2 \mathrm{~min}$, and $80 \mu \mathrm{L}$ of $2-7 \%$ ethidium bromide was added, and was then washed for $20 \mathrm{~min}$ with water, and stained for $10 \mathrm{~min}$ with a gelred solution. The DNA fragment migration patterns were evaluated with a fluorescence microscope at a magnification of $40 \times$ and with an excitation filter of $420-490 \mathrm{~nm}$. The Komet-5 image analysis software developed by Kinetic Imaging, Ltd. (Liverpool, UK) was attached to a CCD [50,51].

\subsubsection{Molecular Analysis}

Real-time PCR was used to evaluate the changes in the relative expression of the APP, MAPT, and Caspase-3 genes in the brain. The total RNA was isolated from the brain tissue using the RNeasy Mini kit (Qiagen), as described by [52]. The integrity and purity of the RNA were assessed by $1 \%$ agarose gel electrophoresis and Nanodrop, respectively. A weight of $4 \mathrm{mg}$ from the obtained RNA was reverse transcribed to cDNA using a quantiscript reverse transcriptase. The produced CDNA was used as a template for real-time PCR reaction in the presence of QuantiTect SYBR Green qPCR Master Mix and gene-specific primers, designed by the Primer 3 web-based tool based on the published rats' sequence (Table 2), along with a StepOnePlus realtime PCR system (Applied Biosystem, Waltham, MA, USA) and reaction cycles, as previously described [53]. The quantities of the critical threshold $(\mathrm{Ct})$ of the target genes were normalized with quantities of the $\mathrm{Ct}$ of the internal control ( $\beta$-actin), as described by [54].

Table 2. Forward and reverse primers sequence used in qPCR.

\begin{tabular}{ccc}
\hline Gene & $\begin{array}{c}\text { Forward Primer } \\
\left.\mathbf{(}^{\prime} 5 \mathbf{-}^{\prime} \mathbf{3}\right)\end{array}$ & $\begin{array}{c}\text { Reverse Primer } \\
\left.\mathbf{(}^{\prime} \mathbf{5}-^{\prime} \mathbf{3}\right)\end{array}$ \\
\hline$A P P$ & AACGAAGACCACTGTGGAGC & CGTCGACAGGCTCAACTTCA \\
MAPT & TGGCTTAAAAGCTGAAGAAGCA & GCCCTTGGCTTTCTTCTCGT \\
Caspase 3 & GGTATTGAGACAGACAGTGG & CATGGGATCTGTTTCTTGC \\
$\beta$-actin & AAGTCCCTCACCCTCCCAAAAG & AAGCAATGCTGTCACCTTCCC \\
\hline
\end{tabular}

\subsubsection{Heavy Metals in Rats' Serum and Liver}

The serum samples were diluted $20 \times$ with a $1 \% \mathrm{HNO}_{3}$ solution and were then used to detect $\mathrm{Cu}, \mathrm{Mn}$, and $\mathrm{Zn}$ with ICP-MS (CETAC Varian 720-ES, Omaha, NE, USA). The concentrations of the three HMs in the liver tissues were also measured by ICP-MS after acid digestion by microwave. A $0.5 \mathrm{~g}$ organic tissue was pre-digested with $5.5 \mathrm{~mL}$ of $\mathrm{HNO}_{3}(68 \%)$ in a PTFE vessel at $110{ }^{\circ} \mathrm{C}$ for half an hour and then transported into a microwave digestion system (MARS 6 classic, CEM, Matthews, NC, USA) for additional mineralization. Three blank samples were similarly examined. The conditions for the digestion of MARS 6 classic were as follows: up to $180^{\circ} \mathrm{C}$ for $25 \mathrm{~min}$ and then constant for $20 \mathrm{~min}$, followed by a cooling stage $(30 \mathrm{~min})$ at $80^{\circ} \mathrm{C}$. Digested samples were diluted with ultrapure water after cooling to room temperature. These samples were used for the final heavy-metal element analysis, performed with an ICP-MS equipped with a concentric Nebulizer, a quartz torch with a quartz injector tube, and a cyclonic spray chamber [55]. 


\subsubsection{Statistical Analysis}

Statistical analysis was carried out using a one-way analysis of variance (ANOVA) test followed by a Duncan test through the program of statistical packages for the social science (SPSS, 16). The results were expressed as mean $\pm \mathrm{SD}$. The differences among means were considered significant at $p<0.05$.

\section{Results and Discussions}

\subsection{Chemical Composition and GC-MS Analysis of Wheat and Barley}

The data in Table 3 showed that wheatgrass has higher protein, fat, and carbohydrate compared with barely; however, barely has a higher fibre. Both have protein around $20 \%$ and low fats around $1.6 \%$.

Table 3. Chemical composition (\%) of germinated dried wheat and barley.

\begin{tabular}{cccccc}
\hline Grass & Proteins & Fats & Fibers & Carbohydrates & Ash \\
\hline Wheat & 21.71 & 1.62 & 18.73 & 31.69 & 12.60 \\
Barely & 22.55 & 1.58 & 22.65 & 24.01 & 15.32 \\
\hline
\end{tabular}

The GC-MS analysis of wheatgrass ethanolic extract demonstrated the occurrence of many bioactive compounds and various pharmacologically essential compounds that contain common compounds extracted belong to hydrocarbon class such as 3-octadecene, unsaturated fatty acids (such as and17-octadecatrienoic acid, 9-Octadecenoic acid and 9,12-Octadecadienoic acid), and esters (such as Cyclopropanebutanoic acid, 2-[[2-[[2[(2-pentylcyclopropyl)meth yl]cyclopropyl]methyl]cyclopropyl] methyl]-, methyl ester) (Table 1). Most of these compounds possess hydroxyl group and/or double bonds that could contribute to the free radical scavenging activity of the wheatgrass extract, because these groups can donate electrons through resonance so as to stabilize the free radicals [56]. Richard in [57] stated that unsaturated fatty acids can act as antioxidants based on their instauration. In addition, the authors of [34] revealed that wheatgrass has a protective effect against genotoxicity and oxidative stress. It contains several antioxidant vitamins such as A, B, C and E; antioxidant content chlorophyll; and antioxidant enzymes such as SOD, cytochrome oxidase, and other enzymes. Banerjee et al. [58] reported that wheatgrass is a plentiful source of numerous flavonoids, mainly apigenin, with anti-oxidant and anti-carcinogenic potentials.

In addition, the GC-MS analysis in Table 4 showed that phytoconstituents in the ethanolic extract of barley grass revealed the presence of three major phytoconstituents (Figure 2). The major phytocomponents reported were dodecane, 9-octadecenoic acid, and ethyliso-allocholate. Panthi et al. [59] also found that the GC-MS analysis of a methanolic extract of barley grass contained fatty acids like 13-docosenic acid and 9,12,15octadecatrienoic acid. They have cancer-preventive, nematicide, anti-arthritic, antiandrogenic, anti-inflammatory, and hypocholesterolemic properties [60].

Table 4. The GC-MS analysis of the ethanolic extract of wheat and barley grasses.

\begin{tabular}{cccccc}
\hline RT & Compound Name & Area \% & \% Peak Area & Formula & MW \\
\hline & & Wheat & & & \\
5.40 & 3-Octadecena & 4.32 & $72,153,576$ & $\mathrm{C}_{18} \mathrm{H}_{34} \mathrm{O}$ & 266 \\
8.93 & Dodecane & 4.20 & $70,048,549$ & $\mathrm{C}_{12} \mathrm{H}_{26}$ & 170 \\
24.32 & 2,2,3,3,4,4 Hexadeutero octadecanal & 2.91 & $48,550,405$ & $\mathrm{C}_{18} \mathrm{H}_{30} \mathrm{D}_{6 \mathrm{O}}$ & 274 \\
27.30 & 17-Octadecynoic acid & 4.80 & $80,057,445$ & $\mathrm{C}_{18} \mathrm{H}_{32} \mathrm{O}_{2}$ & 280 \\
27.54 & 2-Pentadecanone, 6,10,14-trimethyl & 5.31 & $88,654,291$ & $\mathrm{C}_{18} \mathrm{H}_{36} \mathrm{O}$ & 268 \\
27.82 & Ethanol, 2-(9-octadecenyloxy) & 2.68 & $44,757,657$ & $\mathrm{C}_{20} \mathrm{H}_{40} \mathrm{O}_{2}$ & 312 \\
28.20 & 13-Heptadecyn-1-ol & 1.68 & $27,956,548$ & $\mathrm{C}_{17} \mathrm{H}_{32} \mathrm{O}$ & 252 \\
\hline
\end{tabular}


Table 4. Cont

\begin{tabular}{|c|c|c|c|c|c|}
\hline RT & Compound Name & Area \% & $\%$ Peak Area & Formula & MW \\
\hline 29.20 & $\begin{array}{l}\text { Cyclopropanebutanoic acid, 2-[[2-[[2-[(2- } \\
\text { pentylcyclopropyl)methyl]cyclopropyl]methyl }] \text { cyclopropyl }] \\
\text { methyl]-, methyl ester }\end{array}$ & 2.52 & $42,105,270$ & $\mathrm{C}_{25} \mathrm{H}_{42} \mathrm{O}_{2}$ & 374 \\
\hline 30.92 & 9-Octadecenoic acid & 2.00 & $33,361,130$ & $\mathrm{C}_{18} \mathrm{H}_{34} \mathrm{O}_{2}$ & 282 \\
\hline 32.40 & 7-Methyl-Z-tetradecen-1-ol acetate & 6.34 & $105,891,316$ & $\mathrm{C}_{17} \mathrm{H}_{32} \mathrm{O}_{2}$ & 268 \\
\hline 34.20 & 9,12-Octadecadienoic acid & 2.24 & $37,389,728$ & $\mathrm{C}_{18} \mathrm{H}_{32} \mathrm{O}_{2}$ & 280 \\
\hline 44.13 & Ethyl iso-allocholate & 3.31 & $55,267,353$ & $\mathrm{C}_{26} \mathrm{H}_{44} \mathrm{O}_{5}$ & 436 \\
\hline \multicolumn{6}{|c|}{ Barley } \\
\hline 8.92 & Dodecane & 17.03 & $126,128,138$ & $\mathrm{C}_{12} \mathrm{H}_{26}$ & 170 \\
\hline 32.54 & 9Octadecenoic acid & 42.19 & $312,497,160$ & $\mathrm{C}_{18} \mathrm{H}_{34} \mathrm{O}_{2}$ & 282 \\
\hline 44.49 & Ethyliso-allocholate & 40.78 & $302,104,307$ & $\mathrm{C}_{26} \mathrm{H}_{44} \mathrm{O}_{5}$ & 346 \\
\hline
\end{tabular}

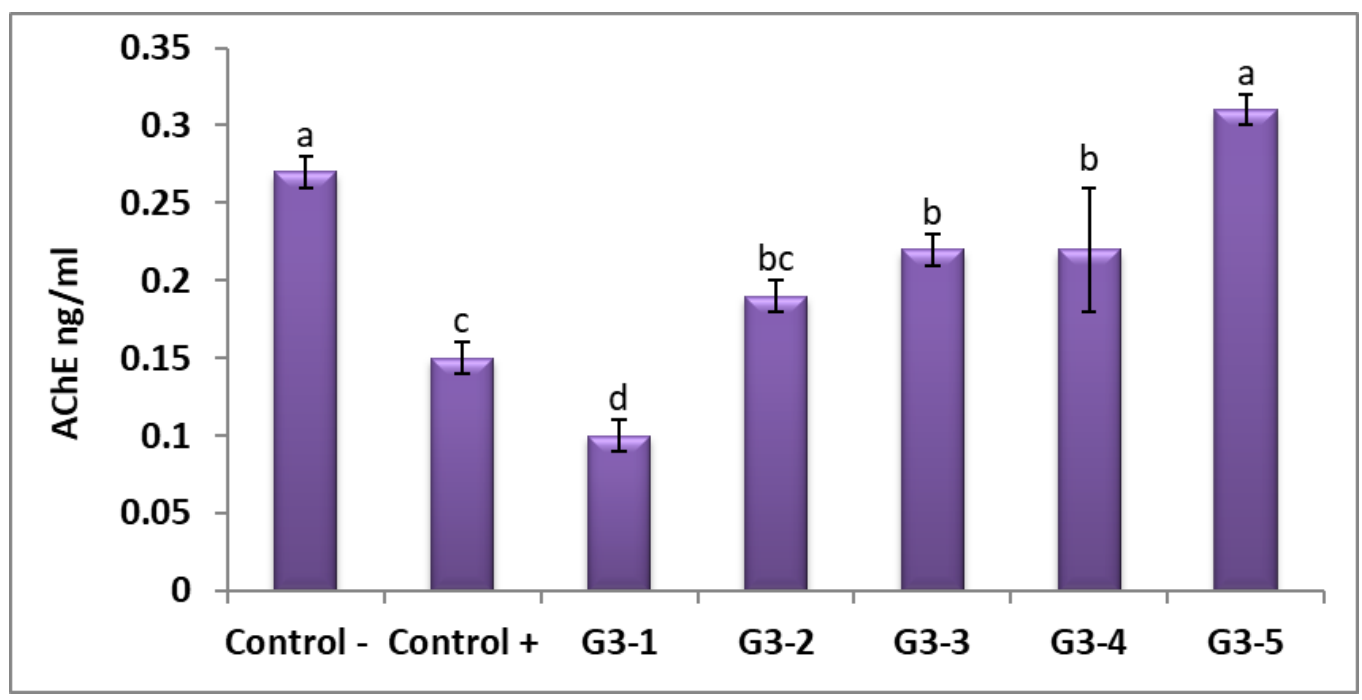

Figure 2. Acetylcholineesterase (AChE) level in rat brains. Values with different letters in each column showed a significant difference.

\subsection{Liver Biomarkers and Hepatocellular Injury Indicators}

The data in Table 5 represent the concentration of plasma ALT, AST, and ALP of the various investigated groups. A significant alteration was noticed in the liver biomarkers in rats subjected to drinking tap water (positive control (+)) and distilled water mixed with HMs (G3-1) compared with distilled water only (negative control (-)). According to the literature [61], toxic metals have negative effects on hepatic functions, biosynthetic efficiency, and the integrity of hepatocytes. The liver weight was significantly lower in control+ and G3-1 than in Control-; however, it was significantly increased in all treatments other than control+ and G3-1. In addition, all of the examined groups (G3-2, G3-3, G3-4, and G3-5) showed a significant reduction in the mean values of ALT than control+ and G3-1. G3-3 and G3-5 exhibited the least ALT values compared with the other treatments, even though G3-5 was less than for Control-, with an insignificant difference. Control+ and G3-1 caused an elevation in AST levels than Control-; however, all other groups recorded a significant decrease compared with control+ and G3-1. The lowest decline in AST was also noticed in G3-5. The tap water and mixed HMs also caused an incremental change in ALP levels; however, G3-2, G3-3, and G3-5 showed a significantly more decreased ALP level than for Control-, control+, and G3-1. It is noticed also that G3-3 and G3-5 recorded the best results for ALT and AST compared with the other treatments. It is shown in [62] that an increase in ALT and AST levels that is out of proportion to ALP and bilirubin implies hepatocellular disease. An increase in ALP and bilirubin levels disproportion to ALT and AST would mean a cholestatic pattern. 
Table 5. Effect of wheat and barley grass on changes in alanine aminotransferase and aspartate aminotransferase, alkaline phosphates, and liver weight in rats exposed to toxic metals (mean $\pm \mathrm{SD}$ ).

\begin{tabular}{ccccc}
\hline Parameters Groups & Liver Weight $(\mathbf{g})$ & ALT(U L & \\
\hline Control - & $9.70 \pm 0.88^{\mathrm{a}}$ & $63.86 \pm 4.07^{\mathrm{e}}$ & $111.40 \pm 2.7^{\mathrm{e}}$ & $70.45 \pm 3.76^{\mathrm{c}}$ \\
Control + & $4.21 \pm 0.06^{\mathrm{d}}$ & $92.73 \pm 2.20^{\mathrm{b}}$ & $180.2 \pm 3.6^{\mathrm{b}}$ & $94.02 \pm 5.03^{\mathrm{b}}$ \\
G3-1 & $4.28 \pm 0.22^{\mathrm{d}}$ & $115.43 \pm 4.8^{\mathrm{a}}$ & $201.4 \pm 7.5^{\mathrm{a}}$ & $108.0 \pm 13.2^{\mathrm{a}}$ \\
G3-2 & $5.51 \pm 0.33^{\mathrm{c}}$ & $83.14 \pm 2.4^{\mathrm{c}}$ & $144.9 \pm 5.0^{\mathrm{c}}$ & $64.34 \pm 4.7^{\mathrm{d}}$ \\
G3-3 & $4.57 \pm 0.29^{\mathrm{d}}$ & $73.47 \pm 2.6^{\mathrm{d}}$ & $126.21 \pm 3.35^{\mathrm{d}}$ & $62.72 \pm 5.7^{\mathrm{d}}$ \\
G3-4 & $5.82 \pm 0.34^{\mathrm{c}}$ & $86.64 \pm 1.4^{\mathrm{c}}$ & $146.33 \pm 3.21^{\mathrm{c}}$ & $78.64 \pm 5.2^{\mathrm{cd}}$ \\
G3-5 & $7.38 \pm 0.28^{\mathrm{b}}$ & $63.44 \pm 3.0^{\mathrm{e}}$ & $119.0 \pm 1.0^{\mathrm{d}}$ & $64.92 \pm 4.8^{\mathrm{d}}$ \\
\hline
\end{tabular}

ALT_alanine aminotransferase; ALP—alkaline phosphatase; AST—aspartate aminotransferase. The values with the different letters in each column showed a significant difference.

According to $[63,64]$, acute HM into intoxications may damage the liver, along with many other organs in the body. Quan et al. [24] stated that wheatgrass juice contains many enzymes that assist in cleansing the body of contaminants and toxins; in addition, amino acids facilitate in detoxifying the liver and removing harmful HMs from the bloodstream, eliminating toxins from the body, and slowing down the ageing process. Calzuola et al. [65] found that the leaf extract of wheatgrass influences the activities of liver enzymes and lipid peroxidation. It has been proven that certain biologically active phytochemicals are released during germination. Kamboj et al. [66] stated that wheatgrass treatment suppressed the increase in liver enzymes based on its dose. Zhang et al. [27] reported that wheatgrass extract contains flavonoids (apigenin) that are known to enhance hepatic functions. It has also been reported that powdered barley grass improved liver function and immunity, it has anti-inflammatory and anticancer inflammatory properties, it helps with weight loss, is hypolipidemic, and prevents cardiovascular disease. In addition, the authors of $[67,68]$ also stated that barley grass and sprouts have many health benefits, including hypolipidemic, hypoglycemic, anticancer, anti-inflammatory constipation prevention, antioxidant properties. Lee et al. and Simeonova et al. [68,69] attributed the protective liver effect and the prevention of an inflamitory to saponarin, which occurs abundantly in barley sprouts.

In Table 6, it is seen that the rats that were administrated tap water and mixed HMs recorded a significant increase in total bilirubin (TB), direct bilirubin (DB), and indirect bilirubin IDB levels. However, all of the treated rat groups (i.e., G3- 2 to G3-5) revealed a significant decline in the mean values of those parameters compared with the G2 and G3-1 groups. It was demonstrated that the wheatgrass extract exerted hepatoprotective mechanisms by improving insulin resistance and lipid metabolism, suggesting the probability of functional diets for improving liver health and overall metabolic syndrome [28]. Ajiboye et al. [70] indicated that a diet rich in phenolic contents could prevent oxidative stress by boosting antioxidant enzymes and reversing liver damage.

Table 6. Effect of wheat and barley grass on changes in the total bilirubin, direct bilirubin, and indirect bilirubin of rats exposed to toxic metals (mean $\pm \mathrm{SD}$ ).

\begin{tabular}{cccc}
\hline Parameters Groups & T.B $\left(\mathbf{m g ~ d L}^{-\mathbf{1}}\right)$ & D.B $\left(\mathbf{m g ~ d L}^{-\mathbf{1}}\right)$ & ID.B $^{\left(\mathbf{m g ~ d L}^{-\mathbf{1}}\right)}$ \\
\hline Control- & $0.55 \pm 0.09^{\mathrm{cd}}$ & $0.09 \pm 0.02^{\mathrm{c}}$ & $0.46 \pm 0.08^{\mathrm{bc}}$ \\
Control+ & $0.85 \pm 0.10^{\mathrm{ab}}$ & $0.18 \pm 0.02^{\mathrm{b}}$ & $0.67 \pm 0.12^{\mathrm{a}}$ \\
G3-1 & $0.87 \pm 0.09^{\mathrm{a}}$ & $0.22 \pm 0.02^{\mathrm{a}}$ & $0.65 \pm 0.12^{\mathrm{a}}$ \\
G3-2 & $0.70 \pm 0.05^{\mathrm{bc}}$ & $0.16 \pm 0.01^{\mathrm{b}}$ & $0.53 \pm 0.04^{\mathrm{ab}}$ \\
G3-3 & $0.55 \pm 0.07^{\mathrm{cd}}$ & $0.12 \pm 0.01^{\mathrm{c}}$ & $0.43 \pm 0.06^{\mathrm{bc}}$ \\
G3-4 & $0.72 \pm 0.10^{\mathrm{ab}}$ & $0.16 \pm 0.01^{\mathrm{b}}$ & $0.56 \pm 0.10^{\mathrm{ab}}$ \\
G3-5 & $0.44 \pm 0.07^{\mathrm{d}}$ & $0.11 \pm 0.02^{\mathrm{c}}$ & $0.33 \pm 0.05^{\mathrm{c}}$ \\
\hline
\end{tabular}

T.B-total bilirubin; D.B-direct bilirubin; ID.B—indirect bilirubin. The values with different letters in each column showed a significant difference. 


\subsection{Protein Fractions}

The results of the protein fractions are presented in Table 7 and show insignificant differences in the plasma concentrations of the total protein, albumin, and globulin of the rats who drank tap water mixed with HMs, and distilled water. In addition, there were insignificant variations among the other treated groups. However, the authors of [61] stated that because of a decline in hepatocytes and a decreased activity, the total protein and albumin were decreased in liver disorders. Phaniendra et al. [71] added that although the poisonous impacts of metals rely on their forms and exposure methods, disorders of intracellular homeostasis involve the destruction to proteins, enzymes, lipids, and DNA through free radical production. Zhang et al. [27] stated that wheatgrass has three abundant composites (choline, $\mathrm{Mg}$, and $\mathrm{K}$ ) that help the liver to remain vital and healthy. Choline prevents fat deposition, Mn assists with drawing out excess fat, and $\mathrm{K}$ acts as an invigorator and stimulant. Because of the barley antioxidant ability, Foda [72] found that after adding young green barley leaf powder to their diet, hypercholesterolemic rat liver and kidney functions improved. Wheatgrass as a source of nutrition improved the protein and albumin levels. It may have a beneficial effect on rat livers [73].

Table 7. Effect of wheat and barley grassed on changes in the total protein, albumin, and globulin of rats exposed to toxic metals (mean $\pm \mathrm{SD}$ ).

\begin{tabular}{ccccc}
\hline Parameters Groups & ${\text { T.P }\left(\mathbf{g ~ d l}^{-\mathbf{1}}\right)}^{\text {ALB }\left(\mathbf{g ~ d l}^{-\mathbf{1}}\right)}$ & G $^{\left(\mathbf{g ~ d l}^{-\mathbf{1}}\right)}$ & A/G \\
\hline Control- & $7.08 \pm 0.15^{\mathrm{abc}}$ & $3.52 \pm 0.10^{\mathrm{ab}}$ & $3.56 \pm 0.25^{\mathrm{ab}}$ & $0.99 \pm 0.10^{\mathrm{b}}$ \\
Control+ & $7.20 \pm 0.07^{\mathrm{a}}$ & $3.46 \pm 0.12^{\mathrm{ab}}$ & $3.73 \pm 0.20^{\mathrm{a}}$ & $0.93 \pm 0.08^{\mathrm{bc}}$ \\
G3-1 & $6.99 \pm 0.11^{\mathrm{bc}}$ & $3.65 \pm 0.11^{\mathrm{a}}$ & $3.34 \pm 0.19^{\mathrm{b}}$ & $1.09 \pm 0.08^{\mathrm{a}}$ \\
G3-2 & $7.15 \pm 0.06^{\mathrm{ab}}$ & $3.61 \pm 0.12^{\mathrm{ab}}$ & $3.53 \pm 0.16^{\mathrm{ab}}$ & $1.02 \pm 0.07^{\mathrm{ab}}$ \\
G3-3 & $6.95 \pm 0.05^{\mathrm{cd}}$ & $3.49 \pm 0.06^{\mathrm{ab}}$ & $3.46 \pm 0.06^{\mathrm{ab}}$ & $1.01 \pm 0.02^{\mathrm{ab}}$ \\
G3-4 & $7.22 \pm 0.04^{\mathrm{a}}$ & $3.62 \pm 0.04^{\mathrm{ab}}$ & $3.59 \pm 0.07^{\mathrm{ab}}$ & $1.01 \pm 0.03^{\mathrm{ab}}$ \\
G3-5 & $6.79 \pm 0.14^{\mathrm{d}}$ & $3.43 \pm 0.15^{\mathrm{b}}$ & $3.36 \pm 0.28^{\mathrm{b}}$ & $1.03 \pm 0.13^{\mathrm{ab}}$
\end{tabular}

T.P—-total protein; ALB—albumin; G—globulin. Values with different letters in each column showed a significant difference.

\subsection{The Concentrations of $\mathrm{Cu}, \mathrm{Mn}$, and $\mathrm{Zn}$ in Rats Serum and Liver Tissues}

The results in Table 8 revealed a significant increase in all of the investigated groups for the plasma concentrations of $\mathrm{Cu}, \mathrm{Mn}$, and $\mathrm{Zn}$. The highest increase was observed in G2 and G3 compared with G1. However, treatment with wheat and barley significantly decreased those concentrations in the studied groups, other than G2 and G3. Treatment with $500 \mathrm{mg}$ wheat and $500 \mathrm{mg}$ barely grasses demonstrated the highest decline in these metals in the investigated rats. The data in Table 7 also demonstrate that the concentrations of $\mathrm{Cu}, \mathrm{Mn}$, and $\mathrm{Zn}$ in the liver tissues increase significantly after exposure to tap water or mixed metals compared with the negative control group. In addition, it is observed that the metal concentrations decreased significantly in all of the considered groups compared with those drinking tap water or the mixed HM groups. According to Stamoulis [73], Zn homeostasis is influenced by $\mathrm{Cu}$. $\mathrm{Cu}$ is found in many proteins, including albumin. Because free $\mathrm{Cu}$ is extremely toxic, it is bound to proteins and one of the most essential $\mathrm{Cu}$ pools is the liver. Increased $\mathrm{Zn}$ levels typically result in lower $\mathrm{Cu}$ concentrations and vice versa. This may by why lower concentrations of $\mathrm{Zn}$ were found in our study compared with $\mathrm{Cu}$ in the serum and liver tissues, even though the exposure to Zn was higher. Dung [74] stated that barley grass supports metabolic processes and helps to strengthen and detoxify the liver. In addition, Wilhelm Filho et al. [75] stated that wheatgrass contains $\mathrm{Ca}, \mathrm{P}, \mathrm{K}$, and Mn, as well as vitamins A, B, and C. It is a strong detoxifier that balances toxins with enzymes and cleanses the body of HMs and other toxins that accumulate in tissues and organs. 
Table 8. Effect of wheat and barley grass on changes in $\mathrm{Cu}, \mathrm{Mn}$, and $\mathrm{Zn}$ in rat serum and liver tissues exposed to those toxic metals (mean $\pm \mathrm{SD}$ ).

\begin{tabular}{|c|c|c|c|}
\hline Parameters Groups & $\mathrm{Zn} \mu \mathrm{g} \mathrm{dL^{-1 }}$ & $C u \mu g d^{-1}$ & $\operatorname{Mn} \mu \mathrm{g} \mathrm{dL}^{-1}$ \\
\hline & & Liver & \\
\hline Control- & $13.68 \pm 2.31^{f}$ & $111.5 \pm 10.03^{\mathrm{e}}$ & $0.29 \pm 0.03^{d}$ \\
\hline Control+ & $31.75 \pm 2.04^{b}$ & $169 \pm 6.55^{\mathrm{b}}$ & $1.08 \pm 0.07^{b}$ \\
\hline G3-1 & $40.94 \pm 3.94^{\mathrm{a}}$ & $250.6 \pm 11.01^{a}$ & $1.78 \pm 0.51^{\mathrm{a}}$ \\
\hline G3-2 & $29.07 \pm 2.03 \mathrm{bc}$ & $153.66 \pm 3.21^{\mathrm{c}}$ & $0.95 \pm 0.04^{\mathrm{cb}}$ \\
\hline G3-3 & $23.72 \pm 1.48^{\mathrm{ed}}$ & $135 \pm 5.00^{\mathrm{d}}$ & $0.69 \pm 0.19^{\mathrm{cb}}$ \\
\hline G3-4 & $26.03 \pm 1.57 \mathrm{~cd}$ & $157.33 \pm 2.51 \mathrm{cb}$ & $1.004 \pm 0.09 \mathrm{cb}$ \\
\hline G3-5 & $20.08 \pm 1.19^{\mathrm{e}}$ & $\begin{array}{c}132.9 \pm 8.5^{\mathrm{d}} \\
\text { Brain }\end{array}$ & $0.63 \pm 0.1^{\mathrm{cd}}$ \\
\hline Control- & $10.29 \pm 0.93^{\mathrm{e}}$ & $77.5 \pm 3.9^{f}$ & $0.13 \pm 0.004^{\mathrm{e}}$ \\
\hline Control+ & $33.62 \pm 0.94^{b}$ & $117.65 \pm 6.05^{b}$ & $0.26 \pm 0.006^{b}$ \\
\hline G3-1 & $42.58 \pm 5.54^{\mathrm{a}}$ & $135 \pm 9^{\mathrm{a}}$ & $0.35 \pm 0.044^{\mathrm{a}}$ \\
\hline G3-2 & $20.03 \pm 1.6^{c}$ & $99.09 \pm 0.98^{c}$ & $0.23 \pm 0.007 \mathrm{cb}$ \\
\hline G3-3 & $14.45 \pm 1.05 \mathrm{ed}$ & $79.65 \pm 4.5^{\text {ef }}$ & $0.19 \pm 0.021^{\mathrm{d}}$ \\
\hline G3-4 & $22.84 \pm 2.1^{c}$ & $91.65 \pm 3.47^{\mathrm{cd}}$ & $0.22 \pm 0.009 \mathrm{dc}$ \\
\hline G3-5 & $15.52 \pm 0.88^{\mathrm{d}}$ & $88.66 \pm 5.1 \mathrm{de}$ & $0.19 \pm 0.10^{\mathrm{d}}$ \\
\hline
\end{tabular}

Values with different letters in each column showed a significant difference.

\subsection{Antioxidant SOD, CAT, and Lipid Peroxide (MDA)}

The administration of tap water and water mixed with HMs resulted in an obvious reduction in some antioxidant levels in the liver tissue, such as catalase (CAT) and glutathione (GSH), compared with the distilled water control group (Table 9). In addition, the stimulated lipid peroxidation was assessed by a significant elevation in the lipid peroxidation by-products of malondialdehyde (MDA) and NO. Banerjee et al. [58] stated that NO is an essential chemical compound that plays a significant role in many inflammation stages. The increase in NO production results in the onset and development of many unhealthy conditions like cancer, type one diabetes, psoriasis, sepsis, colitis, arthritis, and multiple sclerosis. Germinated wheat and barley reduced the MDA and NO levels in the liver tissues and stimulated the antioxidant activity compared with the water mixed with HMs group. Barley grass possesses antioxidant properties [76]. It is abundant in antioxidants (like saponarin, polyphenols, superoxide dismutase (SOD), lutonarin, chlorophyll, Se vitamins (pro-vitamin A, C, and E), and flavonoids) that overturn lipid peroxidation [77]. Thatiparthi et al. [78] showed that barley grass juice has an influential antioxidant activity. Barley sprouts juice hindered the increase of malondialdehyde concentration and the reduction of catalase activities [79]. Quan et al. [24] reported an elevation in the hepatic concentrations of antioxidant enzymes owing to the barley free phenolic extract. In addition, it has been stated [26] that barley sprout extraction has a protective influence on liver cells under oxidative stress through triggering Nrf2 and rising glutathione synthesis, particularly against liver injury caused by alcohol. It has also been shown that phenolic components and vitamins produced through the sprouting of wheatgrass have powerful antioxidant and anti-inflammatory activities [80]. It is clear that the flavonoid-rich wheatgrass diet improved the plasma antioxidant potentials and raised the GSH and CAT levels in rats subjected to toxic HMs. The activity of antioxidants in wheatgrass was noticed at different protection levels, from radical scavenging and suppressing the free radicals that induce membrane damage [81]. Ajiboye et al. [70] stated that wheatgrass decreased MDA and NO levels and consequently increased the activity of the antioxidant enzymes (CAT and GSH), and improved the haematological markers in rats subjected to toxic HMs. This showed that a diet rich in phenolic contents could prevent oxidative stress by enhancing antioxidant enzyme concentrations and opposing liver damage. 
Table 9. Effect of wheat and barley grasses on changes in malondialdehyde, nitric oxide, and some antioxidants levels in the liver homogenate in rats exposed to toxic metals (mean $\pm \mathrm{SD}$ ).

\begin{tabular}{|c|c|c|c|c|}
\hline Parameters & CAT (ng mg ${ }^{-1}$ ) & GSH (ng mg ${ }^{-1}$ ) & NO (nmol mg $\left.{ }^{-1}\right)$ & MDA (nmol mg $\left.{ }^{-1}\right)$ \\
\hline Control- & $0.29 \pm 0.01^{\mathrm{a}}$ & $0.31 \pm 0.02^{\mathrm{a}}$ & $0.10 \pm 0.005^{\mathrm{e}}$ & $0.10 \pm 0.01^{\mathrm{f}}$ \\
\hline Control+ & $0.15 \pm 0.01^{\mathrm{e}}$ & $0.15 \pm 0.01^{\mathrm{e}}$ & $0.19 \pm 0.01^{\mathrm{b}}$ & $0.26 \pm 0.01^{b}$ \\
\hline G3-1 & $0.10 \pm 0.003^{f}$ & $0.11 \pm 0.003^{f}$ & $0.24 \pm 0.01^{\mathrm{a}}$ & $0.32 \pm 0.004^{\mathrm{a}}$ \\
\hline G3-2 & $0.20 \pm 0.01^{\mathrm{d}}$ & $0.19 \pm 0.01^{\mathrm{d}}$ & $0.16 \pm 0.01^{c}$ & $0.20 \pm 0.01^{c}$ \\
\hline G3-3 & $0.23 \pm 0.001^{c}$ & $0.23 \pm 0.01^{c}$ & $0.13 \pm 0.01^{\mathrm{d}}$ & $0.17 \pm 0.002^{\mathrm{d}}$ \\
\hline G3-4 & $0.21 \pm 0.01^{\mathrm{d}}$ & $0.20 \pm 0.01^{\mathrm{d}}$ & $0.18 \pm 0.006^{b}$ & $0.18 \pm 0.01^{\mathrm{d}}$ \\
\hline G3-5 & $0.25 \pm 0.003^{b}$ & $0.26 \pm 0.01^{b}$ & $0.12 \pm 0.01^{\mathrm{d}}$ & $0.13 \pm 0.01^{\mathrm{e}}$ \\
\hline
\end{tabular}

MDA-malondialdehyde (nmol $\mathrm{mg}^{-1}$ protein); NO—nitric oxide (U $\mathrm{min}^{-1} \mathrm{mg}^{-1}$ protein); CAT— catalase ( $\mathrm{U} \mathrm{min}^{-1} \mathrm{mg}^{-1}$ protein); GSH-lutathione (ug mg ${ }^{-1}$ protein). Values with different letters in each column differ significantly.

\subsection{Acetylcholineesterase (AChE) Level in Rat Brains}

The effects of HMs on the acetylcholinesterase activity were evaluated. Heavy metals promoted a significant decrease in acetylcholinesterase activity (G3-1; Figure 2), which has also been reported by [82]. Treatment with wheat and barley grasses reduced the side effects of HMs and recovered the normal concentration of cetylcholinesterase. For barley grass, $500 \mathrm{mg}$ was found to be the best treatment compared with other treatments. Acetylcholinesterase is a vital biomarker for a variety of toxins. Furthermore, the essential function of this enzyme in disorders, that becomes more common in the elderly community, such as Alzheimer's disease, is well recognized [83]. AChE is secreted by cholinergic neurons into the synaptic cleft, where it is usually aligned with the plasma membrane [84]. Hippocampal acetylcholinesterase activity is only slightly decreased in mild cognitive impairment and early Alzheimer's disease [85].

\subsection{Histopathological Observations of Rat Livers Exposed to Contaminated Water and Grasses of Wheat and Barley}

The results of this present study revealed that HMs induced histopathological alterations in rat livers (Figure 3). It has been observed that rats' liver handled with HMs exhibited severe histological effects This includes lymphocytes infiltration, droplets of lipid, and increased collagen fibers around the central vein. Figure 3A,B showed rats' liver in G1 and G2, respectively; they displayed a normal network of hepatocytes central vein. While Figure 3C,D revealed the histological damage that occurred in the liver resulting from rats subjected to HMs, congested central vein, lymphocytes infiltration, droplets of lipid, and increased collagen fibres around the central vein were the major observations. The groups that were subjected to wheatgrass $(250 \mathrm{mg}$ and $500 \mathrm{mg}$ ) and $500 \mathrm{mg}$ barely exhibited a normal liver architecture, while the group of $250 \mathrm{mg}$ barely showed dilated sinusoids with infiltration of lymphocytes. Similar results have been found in the livers of rats subjected to HMs [86]. It has been noticed that toxicant exposed livers show pyknosis and vacuolation. The infiltration of lymphocytes causes the degeneration of liver tissue and necrosis, which are considered as a direct poisonous effect of the contaminates. It is also known that liver injuries increase the serum concentration of ALT, AST, and LDH, in addition to the histological changes that involve damage of the hepatic architecture, cytoplasm vacuolization, ballooned hepatocytes, and necrosis [87,88]. EL-Bady [2] mentioned that liver cirrhosis occurs because of a high $\mathrm{Cu}$ concentration in drinking water; in addition, the authors of [18] also reported that the liver is the key Mn storage organ. In rats, hepatic Mn accumulation persevered significantly longer than in the kidneys and spleen; however, no histopathological damage was observed. The primary pathway of $\mathrm{Mn}$ excretion is the liver (about $80 \%$ of eliminating $\mathrm{Mn}$ ). With weakened liver functions, $\mathrm{Mn}$ accumulation increases the risk of neurodegeneration. It has been stated [21] that wheat grass causes less pronounced histological changes in liver damage by toxic materials. The antioxidant and anti-inflammatory characteristics of wheat grass ingredients inhibit the activation of NF- $\mathrm{kB}[89,90]$. Thatiparthi et al. [78] have stated that using barley grass juice 
enhanced liver functions in rats. In addition, barley grass was found to be a powerful antioxidant that might improve the necrotic changes caused by toxins, as observed in histopathological observations.
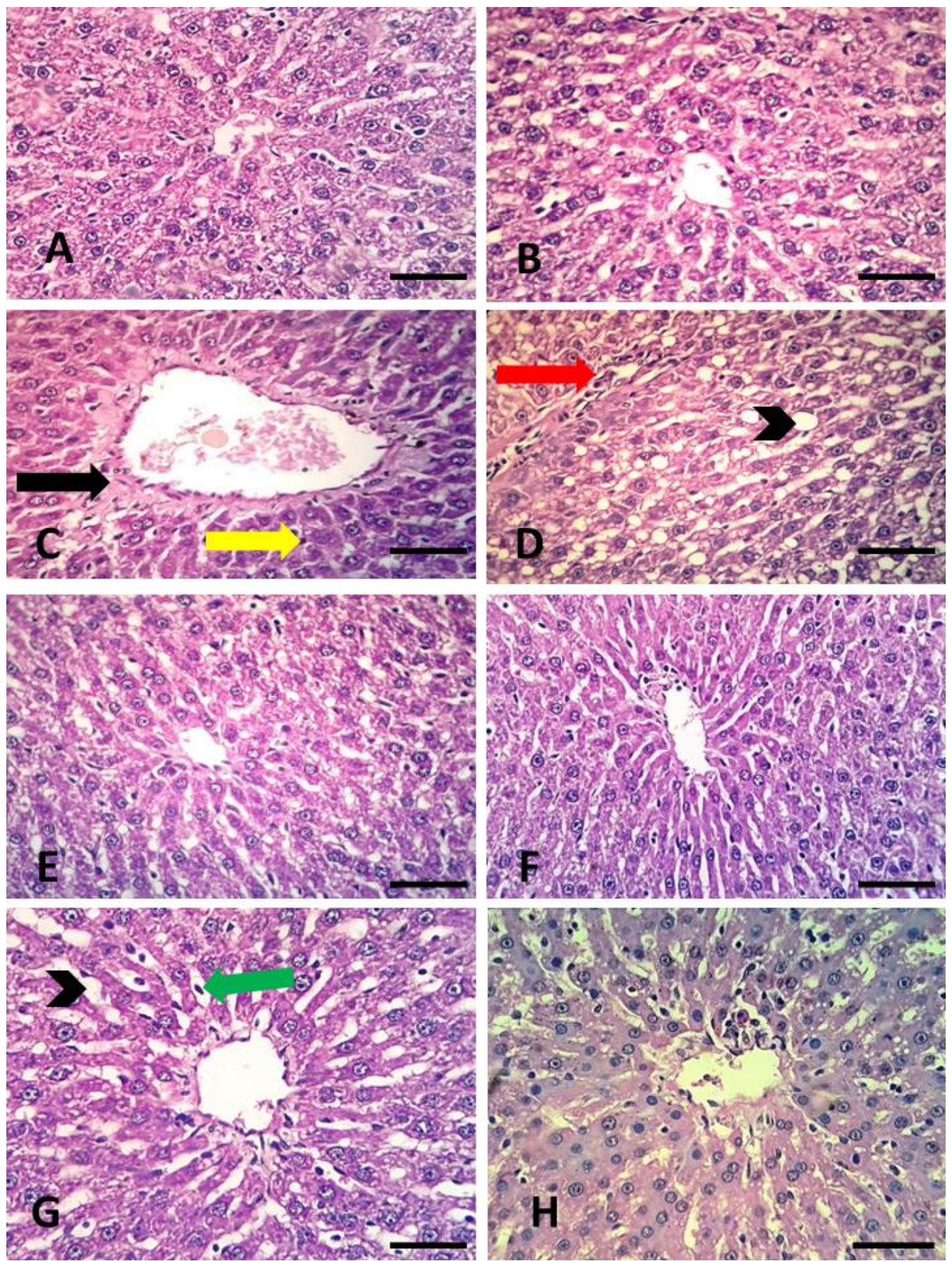

Figure 3. Microscopic pictures of liver sections showing a normal radial arrangement of hepatic cords around central veins with normal sinusoids in the (A) distilled water group and (B) the group of tap water. Liver sections from the control + group $(\mathbf{C}, \mathbf{D})$ showing increased collagen fibres around the central vein (black arrow), circulating leukocytes (yellow arrow), droplets of lipid (head arrow), and infiltration of lymphocytes (red arrow). Liver sections from the group that received (E) 250 and (F) $500 \mathrm{mg}$ wheat grass and (H) $500 \mathrm{mg}$ barely grass appear normal, except for (G) $250 \mathrm{mg}$ barely, which had dilatation in the sinusoids (head arrow) and infiltration of lymphocytes (green arrow). H\&E 400; scale bar $=40$ micron. 
3.8. Comet Assay in Rats Liver Subjected To an Excess of $\mathrm{Cu}, \mathrm{Mn}$, and $\mathrm{Zn}$ and Germinated Wheat and Barley Grasses

A comet assay was performed to estimate the DNA damage in the rat livers subjected to mixed HMs (Figure 4 and Table 10). Significantly high DNA damage $(p<0.05)$ was observed in G3 (C) in the liver, indicated by an increase in tail length, percentage of tail DNA, and tail moment compared with G1 and G2 (Figure 3A,B). The high damage in the liver and brain DNA were both reduced in G3-2, G3-3, G3-4, and G3-5 (Figure 3D-G). However, this reduction remained significantly higher than that of the control groups (A and B). The treatment with $500 \mathrm{mg} \mathrm{kg}^{-1}$ of wheat and barley grasses exhibited the highest reduction in DNA damage. The DNA content was elevated in rats subjected to mixed HMs, while it was reduced up to $50 \%$ with the barley grass treatment $\left(500 \mathrm{mg} \mathrm{kg}^{-1}\right.$; Table 9). These results indicate a genotoxic effect of mixed HMs in the comet assay of exposed rat livers, which offers a sensitive tool to estimate the DNA damage and repair in the genetic toxicology and environmental biomonitoring field [91]. Guecheva et al. [91] stated that $\mathrm{Cu}$ produces reactive oxygen species (ROS), and thus enhanced lipid peroxidation and DNA damage. This damage in the DNA may be important factor in cancer initiation. Bolognesi et al. [92] found that $\mathrm{Cu}$ induced DNA-strand breaking in mussels and mutagenesis through the production of ROS. In addition, experiments revealed that exposure to Mn caused its accumulation in the liver, which enhance ROS generation in the mitochondria and increased single-strand breaks of mitochondrial DNA $[15,91,93,94]$. Furthermore, drinking Mn-contaminated water was associated with chronic Mn poisoning and overflowed from the liver to other organs [95]. In this study, the administration of wheat and barley grasses reduced the DNA damage that was induced by metals. This effect may be related to the different effective ingredients of wheat grass. The aqueous extract of wheat grass is a potential supplier of natural antioxidants. The main components of barley and wheat grasses are ascorbic acid, $\alpha$-tocopherol, SOD, CAT, and glycosylisovitexin, which can reduce the accumulated ROS [96-99].
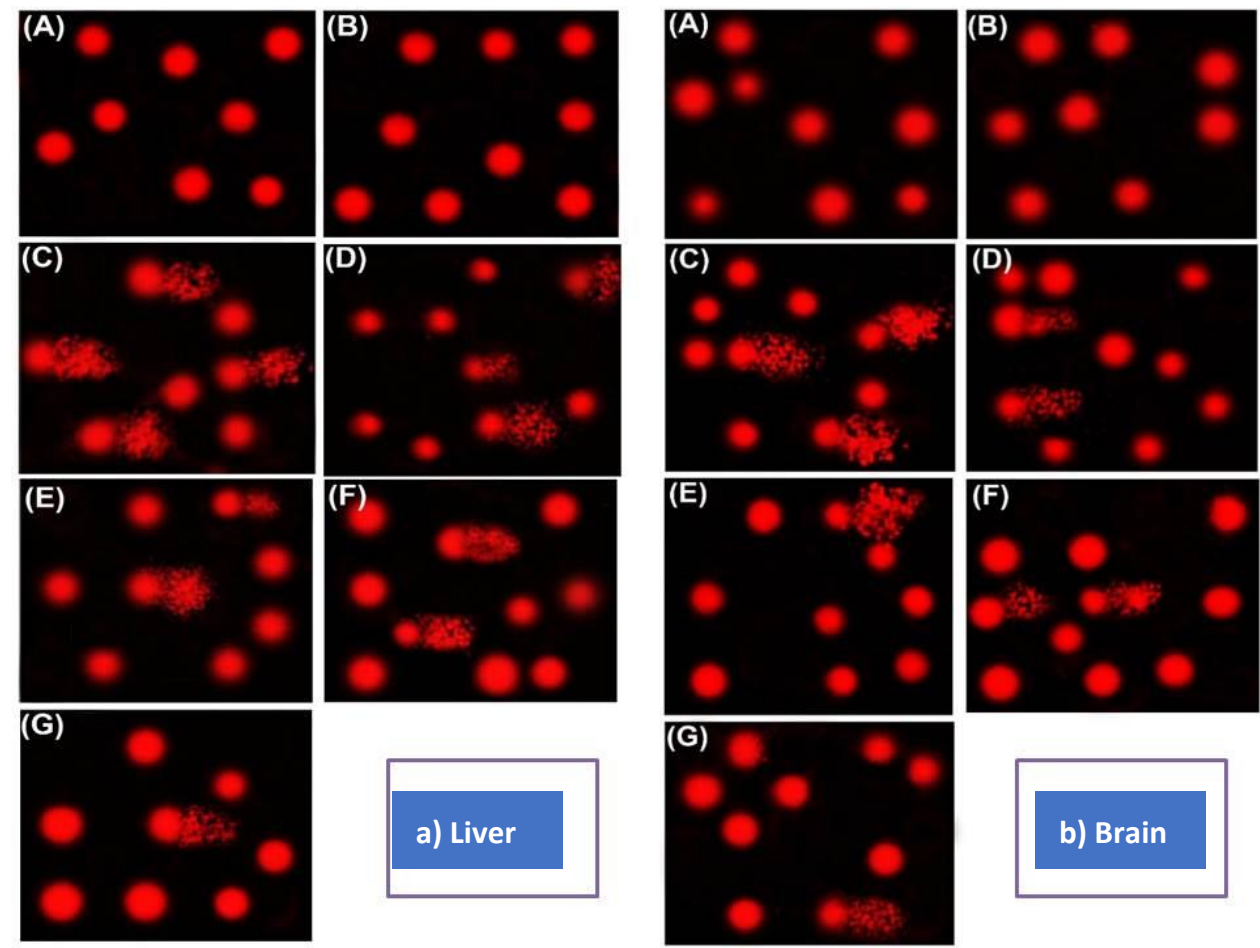

b) Brain

Figure 4. (a) Photomicrographs representation of DNA damage, using comet assay, in rat livers of (A) G1, (B) G2, (C) G3-1, (D) G3-2, (E) G3-3, (F) G3-4, and (G) G3-5. (b) Photomicrographs representation of DNA damage, using comet assay, in rat brains of (A) G1, (B) G2, (C) G3-1, (D) G3-2, (E) G3-3, (F) G3-4, and (G) G3-5. 
Table 10. Comet assay parameters obtained by the image analysis in rat livers and brains for all of the groups.

\begin{tabular}{|c|c|c|c|c|c|c|}
\hline & Group & Tailed \% & $\begin{array}{c}\text { Untailed } \\
\%\end{array}$ & $\begin{array}{c}\text { Tails Length } \\
\mu \mathrm{m}\end{array}$ & $\begin{array}{c}\text { Tail } \\
\text { DNA \% }\end{array}$ & $\begin{array}{c}\text { Tail } \\
\text { Moment }\end{array}$ \\
\hline & \multicolumn{6}{|c|}{ Liver } \\
\hline $\mathbf{A}$ & Control - & 1.75 & 98.25 & $1.25 \pm 0.26^{\mathrm{e}}$ & 1.41 & 1.76 \\
\hline B & Control + & 2.25 & 97.75 & $1.36 \pm 0.24 \mathrm{e}^{\mathrm{e}}$ & 1.45 & 1.97 \\
\hline $\mathrm{C}$ & G3-1 & 14.00 & 86.00 & $4.05 \pm 0.56^{\mathrm{a}}$ & 4.94 & 20.00 \\
\hline D & G3-2 & 9.00 & 91.00 & $2.94 \pm 0.42^{b}$ & 3.43 & 10.08 \\
\hline $\mathbf{E}$ & G3-3 & 6.00 & 94.00 & $2.18 \pm 0.29 \mathrm{~cd}$ & 2.62 & 5.71 \\
\hline $\mathbf{F}$ & G3-4 & 7.00 & 93.00 & $2.33 \pm 0.34^{\mathrm{c}}$ & 2.90 & 6.76 \\
\hline \multirow[t]{2}{*}{ G } & G3-5 & 5.00 & 95.00 & $2.04 \pm 0.24^{\mathrm{d}}$ & 2.46 & 5.02 \\
\hline & \multicolumn{6}{|c|}{ Brain } \\
\hline A & Control - & 2 & 98 & $1.31 \pm 0.24^{\mathrm{d}}$ & 1.39 & 1.82 \\
\hline B & Control + & 2.5 & 97.5 & $1.35 \pm 0.26^{\mathrm{d}}$ & 1.44 & 1.94 \\
\hline $\mathrm{C}$ & G3-1 & 16 & 84 & $4.93 \pm 0.58^{\mathrm{a}}$ & 5.37 & 26.47 \\
\hline D & G3-2 & 10 & 90 & $3.85 \pm 0.48^{b}$ & 3.94 & 15.17 \\
\hline $\mathbf{E}$ & G3-3 & 7 & 93 & $2.35 \pm 0.32^{c}$ & 2.89 & 6.79 \\
\hline F & G3-4 & 9 & 91 & $3.59 \pm 0.40^{b}$ & 3.58 & 12.85 \\
\hline G & G3-5 & 6 & 94 & $2.11 \pm 0.29^{c}$ & 2.60 & 5.49 \\
\hline
\end{tabular}

3.9. Gene Expression of APP, MAPT, and Caspase-3 under Mixed Chemical Minerals Stress in Rat Brain

The expressions of APP, MAPT, and Caspase-3 genes under mixed chemical minerals were measured by qRT-PCR. The treated cells exhibited a significant increase in tested genes compared with the control (G1 and G2). Heavy metal treatment increased the gene expression of APP, MAPT, and Caspase-3 genes, producing a change of up to 2.1-3.81 fold (G3; Figure 5). Treatment with wheat and barley grasses (250 mg kg${ }^{-1}, \mathrm{G} 4$, and G6) decreased the harmful effects of HMs, and the decrease in these gene expressions ranged from 41 to $59 \%$. Otherwise, treatment with $500 \mathrm{mg} \mathrm{kg}^{-1}$ of wheat (G5) and barley grasses (G7) decreased the mRNA level for the tested genes by a ratio of $65-84 \%$. G5 treatment showed the best downregulation in the gene expression of APP, MAPT, and Caspase3 with a decrease in the mRNA level of up to $84 \%$. Amyloid- $\beta$ precursor protein (App) changes in the gene expression have been associated with Alzheimer's disease. Previous research has suggested that the protein products of this gene may play a role in copper homeostasis [100]. The RT-PCR analysis showed the induction of App in brain tissues with mixed chemical minerals treatment (G3). This upregulation was downregulated by wheat and barley grasses. HMs are extremely toxic to the neuron system and consequently induce Alzheimer's disease. Oxidative stress-related apoptosis is concerned with the accumulation of amyloid beta-protein, which is a metabolic product of amyloid precursor protein (APP). Wu et al. [101] showed up-regulated Alzheimer's disease-related genes (APP) in monkey brains following HMs exposure. In particular, snippets of the $\beta$-amyloid precursor protein (APP) resulted in aggregated $\beta$-amyloid $(\mathrm{A} \beta)$ peptides in Alzheimer's disease. Exposure to $\mathrm{Pb}$ early in life results in gene changes through the hypomethylation of the $\mathrm{APP}$ gene, which is a gene responsive to $\mathrm{Pb}$. Hypomethylation results in an overexpression of the APP gene and increases APP production [102]. Tau proteins are mainly expressed in the brain and especially in the neurons. The microtubule-associated protein tau (MAPT) hyperphosphorylation has also been implicated in Alzheimer's disease and other neurological diseases. There is a hypothesis that an MAPT expression reduction would lead to depolymerizing neurofibrillary tangles, and could be involved in Alzheimer's disease and other tauopathies treatment. The authors of [103-106] indicated that HMs promotes tau upregulation and neuronal cell death, whereas wheat and barley grasses downregulate MAPT gene expressions in the brain tissue. The co-administration of wheat and barley grasses with HMs significantly reduced the elevated levels of caspase- 3 observed in the HMs-treated group (downregulation of caspase-3 gene expression). Apoptosis was as- 
sessed using comet assay and caspase 3 gene expression. Apoptosis was relatively more induced by all of the chemicals, which may have been as a result of excess DNA damage.
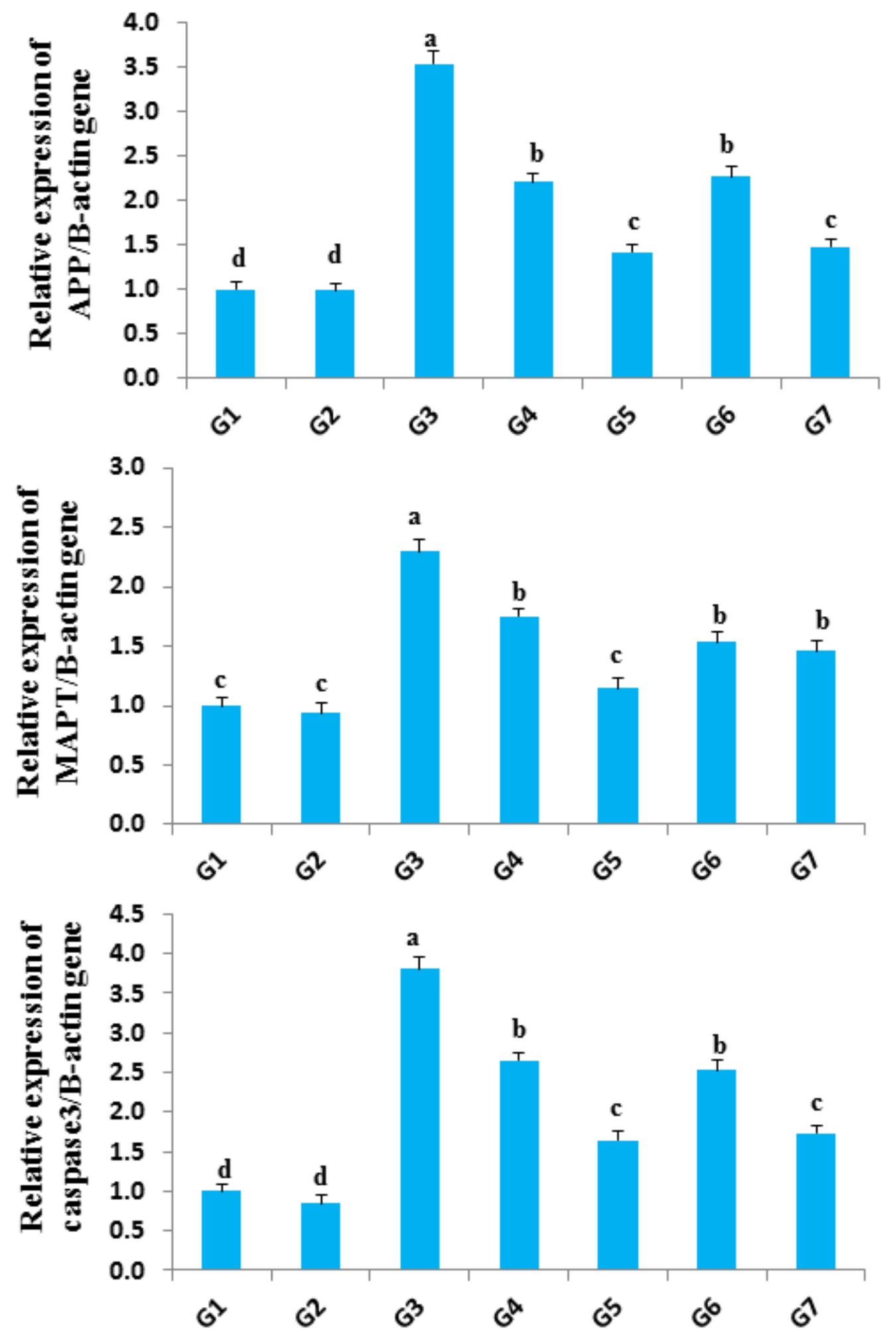

Figure 5. Effect of heavy metal treatment on the expression of APP APP, MAPT, and Caspase3 genes in rat brains.Values with different letters in each column showed a significant difference. 


\section{Conclusions}

Rats administrated with toxic levels of $\mathrm{Cu}, \mathrm{Mn}$, and $\mathrm{Zn}$ exhibited harmful effects in the liver and brain biomarkers. Germinated wheat and barley grasses have many bioactive compounds that likely have protective actions against these harmful effects. Especially at high doses, these treatments enhanced the liver biomarkers and hepatocellular injury indicators in rats administrated with toxic metals in drinking water for 60 days, and reduced the concentrations of these metals in the serum and liver. In addition, they helpd the liver recover from severe histopathological effects and reach the normal concentration of acetylcholinesterase, and reduced the damage to DNA in the liver and brain. Previous studies about germinated seeds have not focussed on recovering from the harmful effects of heavy metals; however, this study highlights that the use of germinated seeds is promising to avoid the many health-damaging effects of heavy metals. Although the use of germinated wheat and barley grasses revealed many advantages in helping the liver and brain recover against toxic heavy metals, more studies are needed in this field in order to better understand their interface and the mechanism of their effects on the livers and brains of living organisms generally. In addition, future studies also are required to study the potential risks of consuming overdoses of germinated seeds on the liver and brain parameters.

Author Contributions: Conceptualization, H.S.E.E., H.E., A.M.E., and A.Z.; data curation, A.M.E., M.R., D.A.E.M., and A.Z.; formal analysis, H.S.E.E., H.E., A.M.E., L.M.A.E.-M., and O.I.E.-D.; investigation, H.S.E.E., H.E., A.M.E., L.M.A.E.-M., O.I.E.-D., and A.Z.; methodology, H.E. and H.S.E.E.; project administration, H.S.E.E. and H.E.: resources, H.S.E.E., H.E., A.M.E., L.M.A.E.-M., O.I.E.-D., M.R., D.A.E.M., and A.Z.; validation, H.S.E.E., H.E., A.M.E., L.M.A.E.-M., O.I.E.-D., M.R., D.A.E.M., and A.Z.; visualization, H.S.E.E. and H.E.; writing-original draft, H.S.E.E., H.E., A.M.E., L.M.A.E.M., O.I.E.-D., M.R., D.A.E.M., and A.Z.; writing—review and editing, H.S.E.E., H.E., A.M.E., L.M.A.E.M., O.I.E.-D., M.R., D.A.E.M., and A.Z. All authors have read and agreed to the published version of the manuscript.

Funding: This research received no external funding.

Institutional Review Board Statement: The Institutional Aquatic Animal Care and Use Committee, Faculty of Aquatic and Fisheries Sciences, Kafrelsheikh University, Egypt, approved the conduct of this trial (approval number: IAACUC-KSU-136-2020).

Informed Consent Statement: Not applicable.

Data Availability Statement: Not applicable.

Acknowledgments: The authors thank Raddy Ali Mohamed (IAACUC-KSU) for his advice and cooperation to perform this research.

Conflicts of Interest: The authors declare no conflict of interest.

\section{References}

1. Mandour, R.A. Human health impacts of drinking water (surface and ground) pollution Dakahlyia Governorate, Egypt. Appl. Water Sci. 2012, 2, 157-163. [CrossRef]

2. EL-Bady, M.S. Toxic levels of some heavy metals in drinking network surface water of Damietta governorate, Egypt. Drink. Water Eng. Sci. Discuss. 2016, 1-8.

3. Pecina, V.; Brtnický, M.; Baltazár, T.; Juřička, D.; Kynický, J.; Galiová, M.V. Human health and ecological risk assessment of trace elements in urban soils of 101 cities in China: A meta-analysis. Chemosphere 2020, 267, 129215. [CrossRef]

4. Ullah, I.; Ditta, A.; Imtiaz, M.; Mehmood, S.; Rizwan, M.; Rizwan, M.S.; Ahmad, I. Assessment of health and ecological risks of heavy metal contamination: A case study of agricultural soils in Thall, Dir-Kohistan. Environ. Monit. Assess. 2020, 192, 1-19. [CrossRef]

5. Masoumi, H.; Ghaemi, A.; Gilani, H.G. Evaluation of hyper-cross-linked polymers performances in the removal of hazardous heavy metal ions: A Review. Sep. Purif. Technol. 2020, 260, 118221. [CrossRef]

6. Keshavarzi, A.; Kumar, V.; Ertunç, G.; Brevik, E.C. Ecological risk assessment and source apportionment of heavy metals contamination: An appraisal based on the Tellus soil survey. Environ. Geochem. Health 2021, 43, 1-22. [CrossRef]

7. Schlutow, A.; Schröder, W.; Scheuschner, T. Assessing the relevance of atmospheric heavy metal deposition with regard to ecosystem integrity and human health in Germany. Environ. Sci. Eur. 2021, 33, 1-34. [CrossRef] 
8. Singh, B.P.; Tandon, P.K. Effect of river water pollution on hematological parameters of fish, Wallagoattu. Res. Environ. Life Sci. 2009, 2, 211-214.

9. Reddy, U.A.; Prabhakar, P.V.; Rao, G.S.; Rao, P.R.; Sandeep, K.; Rahman, M.F.; Mahboob, M. Biomarkers of oxidative stress in rat for assessing toxicological effects of heavy metal pollution in river water. Environ. Sci. Pollut. Res. 2015, 22, 13453-13463. [CrossRef] [PubMed]

10. Zhang, X.; Guo, S.; Liu, J.; Zhang, Z.; Song, K.; Tan, C.; Li, H. A study on the removal of copper (II) from aqueous solution using lime sand bricks. Appl. Sci. 2019, 9, 670. [CrossRef]

11. Sadeghi, P.; Savari, A.; Movahedinia, A.; Safahieh, A.; Azhdari, D. An assessment of hematological and biochemical responses in the tropical fish Epinephelus stoliczkae of Chabahar Bay and Gulf of Oman under chromium exposure: Ecological and experimental tests. Environ. Sci. Pollut. Res. 2014, 21, 6076-6088. [CrossRef]

12. Elbasiouny, H.; Elbehiry, F. Mobility and Potential Ecological Risk Assessment of Copper and Zinc in Alluvial and Marine Soils in The North Nile Delta, Egypt. Environ. Biodivers. Soil Secur. 2019, 3, 255-268. [CrossRef]

13. Tang, H.; Xu, M.; Luo, J.; Zhao, L.; Ye, G.; Shi, F.; Lv, C.; Chen, H.; Wang, Y.; Li, Y. Liver toxicity assessments in rats following sub-chronic oral exposure to copper nanoparticles. Environ. Sci. Eur. 2019, 31, 30. [CrossRef]

14. WHO. Guidelines for Drinking-Water Quality, 4th ed.; World Health Organization: Geneva, Switzerland, 2011.

15. Huang, Y.; Wang, B.; Liu, G.; Ge, W.; Zhang, M.; Yue, B.; Kong, M. Effects of Bacillus Subtilis-Zinc on Rats with Congenital Zinc Deficiency. Biol. Trace Element Res. 2020, 194, 482-492. [CrossRef] [PubMed]

16. Wilk, A.; Szypulska-Koziarska, D.; Marchelek-Myśliwiec, M.; Głazek, W.; Wiszniewska, B. Serum Selenium, Iron, Zinc, and Copper Concentrations in Renal Transplant Recipients Treated with Mycophenolate Mofetil. Biol. Trace Element Res. 2020, 198, 371-379. [CrossRef] [PubMed]

17. Abdeldayem, R. A preliminary study of yy metals pollution risk in water. Appl. Water Sci. 2020, 10, 1. [CrossRef]

18. O'Neal, S.L.; Zheng, W. Manganese toxicity upon overexposure: A decade in review. Curr. Environ. Health Rep. 2015, 2, 315-328. [CrossRef]

19. Pakfetrat, S.; Amiri, S.; Radi, M.; Abedi, E.; Torri, L. Reduction of phytic acid, aflatoxins and other mycotoxins in wheat during germination. J. Sci. Food Agric. 2019, 99, 4695-4701. [CrossRef]

20. Benedetti, S.; Primiterra, M.; Tagliamonte, M.C.; Carnevali, A.; Gianotti, A.; Bordoni, A.; Canestrari, F. Counteraction of oxidative damage in the rat liver by an ancient grain (Kamut brand khorasan wheat). Nutrition 2012, 28, 436-441. [CrossRef]

21. Nepali, S.; Ki, H.H.; Lee, J.H.; Cha, J.Y.; Lee, Y.M.; Kim, D.K. Triticum aestivum sprout-derived polysaccharide exerts hepatoprotective effects against ethanol-induced liver damage by enhancing the antioxidant system in mice. Int. J. Mol. Med. 2017, 40, 1243-1252. [CrossRef]

22. Stevenson, L.; Phillips, F.; O'Sullivan, K.; Walton, J. Wheat bran: Its composition and benefits to health, a European perspective. Int. J. Food Sci. Nutr. 2012, 63, 1001-1013. [CrossRef] [PubMed]

23. Leoncini, E.; Prata, C.; Malaguti, M.; Marotti, I.; Segura-Carretero, A.; Catizone, P.; Dinelli, G.; Hrelia, S. Phytochemical profile and nutraceutical value of old and modern common wheat cultivars. PLoS ONE 2012, 7, e45997. [CrossRef]

24. Quan, M.; Li, Q.; Zhao, P.; Tian, C. Chemical composition and hepatoprotective effect of free phenolic extract from barley during malting process. Sci. Rep. 2018, 8, 4460. [CrossRef]

25. Obadi, M.; Sun, J.; Xu, B. Highland barley: Chemical composition, bioactive compounds, health effects, and applications. Food Res. Int. 2021, 140, 110065. [CrossRef] [PubMed]

26. Lee, Y.H.; Kim, S.H.; Lee, S.; Kim, K.M.; Jung, J.C.; Son, T.G.; Ki, S.H.; Seo, W.D.; Kwak, J.H.; Hong, J.T.; et al. Antioxidant effect of barley sprout extract via enhancement of nuclear factor-erythroid 2 related factor 2 activity and glutathione synthesis. Nutrients 2017, 9, 1252. [CrossRef] [PubMed]

27. Zhang, J.; Zhao, L.; Cheng, Q.; Ji, B.; Yang, M.; Sanidad, K.Z.; Wang, C.; Zhou, F. Structurally different flavonoid subclasses attenuate high-fat and high-fructose diet induced metabolic syndrome in rats. J. Agric. Food Chem. 2018, 66, 12412-12420. [CrossRef] [PubMed]

28. Oh, H.S.; Cho, W.; Tak, S.B.; Kim, S.; Hong, S.P.; Kim, S.O. Triticum aestivum ethanolic extract improves non-alcoholic fatty liver disease in mice fed a choline-deficient or high-fat diet. J. Sci. Food Agric. 2019, 99, 2602-2609. [CrossRef] [PubMed]

29. Egyptian Ministry of Health, E.M.H. Standards and Specifications of Water Quality for Drinking and Domestic Uses; Internal Report; Egyptian Ministry of Health: Cairo, Egypt, 2007; pp. 1-8.

30. American Public Health Association. Standard Methods for the Examination of Water and Waste Water, 22nd ed.; American Water Works Association, Water Environment Federation: Washington, DC, USA, 2012.

31. Jain, G.; Argal, A. Hepatoprotective potential of young leaves of Triticum aestivum Linn. against CCl4 induced hepatotoxicity. Int. J. Pharm. Sci. Res. 2014, 5, 4751-4755.

32. Malla, S.; Mourya, M.K.; Halder, D.; Gomroki, F.; Mohammed, H. Healing effects of Wheat Grass (Triticum aestivum L) extracts on RBC Membrane Damage. Am. J. Life Sci. 2014, 2, 22. [CrossRef]

33. American Association of Cereal Chemists. Approved Methods of American Association of Cereal Chemists, 10th ed.; AACC: St. Paul, MN, USA, 2000.

34. Abed, K.A.K.; Yaqoob, K.; Abdoh, A.O.O.; Mohammed, S.M.; Pankaj, T.; Hakeem, S.M.A.; Mamoon, H.S. Investigation of Antigenotoxic Potential of Wheatgrass (Triticumaestivum) Powder on Cyclophosphamide Induced Genotoxicity and Oxidative Stress in Mice. Austin J. Pharmacol. Ther. 2017, 5, 1098. 
35. Reitman, S.; Frankel, S.A. Colorimetric method for the determination of sGOT and sGPT. Am. J. Clin. Pathol. 1957, 28, 56-63. [CrossRef] [PubMed]

36. Klein, B.; Read, P.A.; Babson, L.A. Effects of Ocimum basilicum on tissue anti-oxidant pathways in normal and streptozotocindiabetic rats. Clin. Chem. 1960, 6, 269-275. [CrossRef] [PubMed]

37. Walters, M.I.; Gerard, H.W. An ultramicromethod for the determination of conjugated and total bilirubin in serum or plasma. Microchem. J. 1970, 15, 231-243. [CrossRef]

38. Bowers, L.; Wong, E. Kinetic serum creatinine assays II. A critical evaluation and review. Clin. Chem. 1980, 26, 555-561. [CrossRef]

39. Doumas, B.T.; Watson, W.A.; Biggs, H.G. Albumin standards and the measurement of serum albumin with bromocresol green. Clin. Chim. Acta 1977, 31, 87-96. [CrossRef]

40. Allain, C.C.; Poon, L.S.; Chan, C.S.; Richmond, W.; Fu, P.C. Enzymaticdetermination of total cholesterol. Clin. Chem. 1974, 20, 470-475. [CrossRef]

41. Albers, J.J.; Warnick, G.R.; Cheung, M.C. Quantification of high density lipoproteins. Lipids 1978, 13, 926-932. [CrossRef]

42. Bucolo, G.; David, H. Quantitativedetermination of serum triglycer-331ides by use of enzymes. Clin. Chem. 1973, 19, 476-482. [CrossRef]

43. Warnick, G.R.; Knopp, R.H.; Fitzpatrick, V.; Branson, L. Estimatinglow-density lipoprotein cholesterol by the Friedewald equation is408adequate for classifying patients on the basis of nationally recommended cut points. Clin. Chem. 1990, 36, 15-19. [CrossRef]

44. Suvarna, K.S.; Layton, C.; Bancroft, J.D. Bancroft's Theory and Practice of Histological Techniques, 7th ed.; Churchill Livingstone; Elsevier: Oxford, UK, 2013; p. 654.

45. Aebi, H. Catalase in vitro. Methods Enzymol. 1984, 105, 121-126.

46. Paglia, D.E.; Valentine, W.N. Studies on the quantitative and qualitative characterization of erythrocyte glutathione peroxidase. J. Lab. Clin. Med. 1967, 70, 158-169.

47. Ohkawa, H.; Ohishi, N.; Yagi, K. Assay of lipid peroxides in animal tissues by thiobarbituric acid reaction. Anal. Biochem. 1979, 95, 351-358. [CrossRef]

48. Archer, S. Measurement of nitric oxide in biological models. FASEB J. 1993, 7, 340-360. [CrossRef] [PubMed]

49. Carageorgiou, H.; Tzotzes, V.; Sideris, A.; Zarros, A.; Tsakiris, S. Cadmium effects on brain acetylcholinesterase activity and antioxidant status of adult rats: Modulation by zinc, calcium and L-cysteine co-administration. Basic Clin. Pharmacol. Toxicol. 2005, 97, 320-324. [CrossRef] [PubMed]

50. Olive, P.L.; Bánath, J.P. The comet assay: A method to measure DNA damage in individual cells. Nat. Protoc. 2006, 1, 23-29. [CrossRef]

51. Pozos, P.G.I.; Ruiz-López, M.A.; Zamora Natera, J.F.; Alvarez Moya, C.; Barrientos Ramirez, L.; Reynoso Silva, M.; Vargas Radillo, J.J. Antioxidant Capacity and Antigenotoxic Effect of Hibiscus sabdariffa L. Extracts Obtained with Ultrasound-Assisted Extraction Process. Appl. Sci. 2020, 10, 560. [CrossRef]

52. Abd-Allah, S.H.; Shalaby, S.M.; Abd-Elbary, E.; Saleh, A.A.; Abu El-Magd, M. Human peripheral blood CD34+ cells attenuate oleic acid-induced acute lung injury in rats. Cytotherapy 2015, 17, 443-453. [CrossRef]

53. Khamis, A.A.; Ali, E.M.; El-Moneim, M.A.A.; Abd-Alhaseeb, M.; Abu El-Magd, M.; Salim, E.I. Hesperidin, piperine and bee venom synergistically potentiate the anticancer effect of tamoxifen against breast cancer cells. Biomed. Pharmacother. 2018, 105, 1335-1343. [CrossRef]

54. El-Magd, M.A.; Khamis, A.; Eldeen, S.K.N.; Ibrahim, W.M.; Salama, A.F. Trehalose enhances the antitumor potential of methotrexate against mice bearing Ehrlich ascites carcinoma. Biomed. Pharmacother. 2017, 92, 870-878. [CrossRef]

55. Wang, Y.; Tang, Y.; Li, Z.; Hua, Q.; Wang, L.; Song, X.; Tang, C. Joint toxicity of a multi-heavy metal mixture and chemoprevention in sprague dawley rats. Int. J. Environ. Res. Public Health 2020, 17, 1451. [CrossRef]

56. Shakya, G.; Pajaniradje, S.; Hoda, M.; Durairaj, V.; Rajagopalan, R. GC-MS analysis, in vitro antioxidant and cytotoxic studies of wheatgrass extract. Am. J. Phytomed. Clin. Ther. 2014, 2, 877-893.

57. Richard, D.; Kefi, K.; Bausero, P.; Visioli, F. Polyunsaturated fatty acids as antioxidants. Pharmacol. Res. 2008, 57, 451-455. [CrossRef]

58. Banerjee, S.; Katiyar, P.; Kumar, V.; Waghmode, B.; Nathani, S.; Krishnan, V.; Sircar, D.; Roy, P. Wheatgrass inhibits the lipopolysaccharide-stimulated inflammatory effect in RAW 264.7 macrophages. Curr. Res. Toxicol. 2021, 2, 116-127. [CrossRef]

59. Panthi, M.; Kumar, R.; Raut, S.; Khanal, D.P.; Koirala, N. Bioactivity evaluations of leaf extract fractions from young barley grass and correlation with their phytochemical profiles. BMC Complement. Med. Ther. 2020, 20, 64. [CrossRef] [PubMed]

60. Erdinest, N.; Shmueli, O.; Grossman, Y.; Ovadia, H.; Solomon, A. Anti-inflammatory effects of alpha linolenic acid on human corneal epithelial cells. Investig. Opthalmol. Vis. Sci. 2012, 53, 4396-4406. [CrossRef]

61. Bamidele, A.; Ayannuga, S.; Olugbenga, O. Hepatoprotective potentials of methanolic extract of the leaf of momordicacharantialinn on cadmium -induced hepatotoxicity in rats. J. Nat. Sci. Res. 2012, 2, 41-47.

62. Lala, V.; Goyal, A.; Bansal, P.; Minter, D.A. Liver Function Tests; StatPearls Publishing: Treasure Island, FL, USA, 2021. [PubMed]

63. Jang, D.H.; Hoffman, R.S. Heavy metal chelation in neurotoxic exposures. Neurol. Clin. 2011, 29, 607-622. [CrossRef] [PubMed]

64. Adal, A.; Wiener, S.W. Heavy Metal Toxicity. Medscape. 2013. Available online: http:// emedicine.medscape.com/article/814960 -overview (accessed on 10 August 2020).

65. Calzuola, I.; Valeria, M.; Gianfranceschi, G.L. Synthesis of antioxidants in wheat sprouts. J. Agric. Food Chem. 2014, 52, 5201-5206. [CrossRef] [PubMed] 
66. Kamboj, J.K.; Rana, S.V.; Ola, R.P.; Dhawan, D.K.; Vahiphei, K. Wheatgrass and Antioxidant Levels in Carbon Tetrachlorideinduced Hepatotoxicity in Rats. J. Clin. Exp. Hepatol. 2011, 1, 43. [CrossRef]

67. Lahouar, L.; El-Bok, S.; Achour, L. Therapeutic potential of young green barley leaves in prevention and treatment of chronic diseases: An overview. Am. J. Chin. Med. 2015, 43, 1311-1329. [CrossRef] [PubMed]

68. Lee, Y.H.; Kim, J.H.; Kim, S.H.; Oh, J.Y.; Seo, W.D.; Kim, K.M.; Jung, J.C.; Jung, Y.S. Barley sprouts extract attenuates alcoholic fatty liver injury in mice by reducing inflammatory response. Nutrients 2016, 8, 440. [CrossRef] [PubMed]

69. Simeonova, R.; Kondeva-Burdina, M.; Vitcheva, V.; Krasteva, I.; Manov, V.; Mitcheva, M. Protective effects of the apigenin-O/Cdiglucoside saponarin from Gypsophila trichotoma on carbone tetrachloride-induced hepatotoxicity in vitro/in vivo in rats. Phytomedicine 2014, 21, 148-154. [CrossRef]

70. Ajiboye, B.O.; Oloyede, H.O.B.; Salawu, M.O. Antidiabetic activity of Triticum aestivum seed-based diet on alloxan-induced diabetic rats. J. Diet. Suppl. 2020, 17, 133-149. [CrossRef]

71. Phaniendra, A.; Jestadi, D.B.; Periyasamy, L. Free radicals: Properties, sources, targets, and their implication in various diseases. Ind. J. Clin. Biochem. 2015, 30, 11-26. [CrossRef]

72. Foda, M. Biochemical Studies on Antioxidants Extracted from young Green Barley Leaves. Master's Thesis, Department of Biochemistry, Faculty of Agriculture, Benha University, Benha, Egypt, 2010.

73. Stamoulis, I.; Kouraklis, G.; Theocharis, S. Zinc and the Liver: An Active Interaction. Dig. Dis. Sci. 2007, 52, 1595-1612. [CrossRef] [PubMed]

74. Dung, D.D.; Godwin, R.; Nolan, I.V. Barley Grain and Sprouted Barley. J. Anim. Vet. Adv. 2010, 9, $2485-2492$.

75. Wilhelm Filho, D.; Júnior, S.Á.; Possamai, F.P.; Parisotto, E.B.; Moratelli, A.M.; Garlet, T.R.; Inácio, D.B.; Torres, M.A.; Colepicolo, P.; DalPizzol, F. Antioxidant therapy attenuates oxidative stress in the blood of subjects exposed to occupational airborne contamination from coal mining extraction and incineration of hospital residues. Ecotoxicology 2010, 19, 1193-1200. [CrossRef]

76. Deng, L.; Feng, G.; Gao, Y.; Shen, Y.; Li, H.; Gu, Y.; Luan, H. Phytochemical Constituents and Antioxidant Enzyme Activity Profiles of Different Barley (Hordeum Vulgare L.) Cultivars at Different Developmental Stages. Agronomy 2020, 10, 37. [CrossRef]

77. Zeng, Y.; Pu, X.; Yang, X.; Yang, J.; Du, J.; Yang, T.; Li, X. Strategies of functional foods for heart disease prevention in human beings. In Proceedings from the ICERP 2016; Sciendo Migration: Warsaw, Poland; pp. 108-123.

78. Thatiparthi, J.; Dodoala, S.; Koganti, B.; Kvsrg, P. Barley grass juice (Hordeum vulgare L.) inhibits obesity and improves lipid profile in high fat diet-induced rat model. J. Ethnopharmacol. 2019, 238, 111843. [CrossRef]

79. Mohamed, R.S.; Diaa, M.A.; Salah, H.S.; Ahmed, H.Z.; Ihab, A.S.; Abdel Razik, F.H.; Ahmed, A.M. Hypoglycemic, hypolipidemic and antioxidant effects of green sprouts juice and functional dairy micronutrients against streptozotocin-induced oxidative stress and diabetes in rats. Heliyon 2019, 5, 01197. [CrossRef] [PubMed]

80. Luyen, B.T.; Tai, B.H.; Thao, N.P.; Cha, J.Y.; Lee, Y.M.; Kim, Y.H. A new phenolic component from Triticum aestivum sprouts and its effects on LPS-stimulated production of nitric oxide and TNF-alpha in RAW 264.7 cells. Phytother. Res. 2014, 28, 1064-1070. [CrossRef]

81. Chauhan, M. A pilot study on wheat grass juice for its phytochemical, nutritional and therapeutic potential on chronic diseases. Int. J. Chem. Stud. 2014, 2, 27-34.

82. Richetti, S.K.; Rosemberg, D.B.; Ventura-Lima, J.; Monserrat, J.M.; Bogo, M.R.; Bonan, C.D. Acetylcholinesterase activity and antioxidant capacity of zebrafish brain is altered by heavy metal exposure. Neurotoxicology 2011, 32, 116-122. [CrossRef] [PubMed]

83. Kim, B.; Backus, C.; Oh, S.; Hayes, J.M.; Feldman, E.L. Increased tau phosphorylation and cleavage in mouse models of type 1 and type 2 diabetes. Endocrinology 2009, 150, 5294-5301. [CrossRef] [PubMed]

84. Ferreira-Vieira, T.H.; Guimaraes, I.M.; Silva, F.R.; Ribeiro, F.M. Alzheimer's disease: Targeting the Cholinergic System. Curr. Neuropharmacol. 2016, 14, 101-115. [CrossRef] [PubMed]

85. Rinne, J.O.; Kaasinen, V.; Järvenpää, T.; Någren, K.; Roivainen, A.; Yu, M.; Oikonen, V.; Kurki, T. Brain acetylcholinesterase activity in mild cognitive impairment and early Alzheimer's disease. J. Neurol. Neurosurg. Psychiatry 2003, 74, 113-115. [CrossRef]

86. Van Dyk, J.C.; Pieterse, G.M.; Van Vuren, J.H. Histological changes in the liver of Oreochromis mossambicus (Cichlidae) after exposure to cadmium and zinc. Ecotoxicol. Environ. Saf. 2007, 66, 432-440. [CrossRef]

87. Xu, D.; Hu, L.; Su, C.; Xia, X.; Zhang, P.; Fu, J.; Wang, W.; Xu, D.; Du, H.; Hu, Q.; et al. Tetrachloro-p-benzoquinone induces hepatic oxidative damage and inflammatory response, but not apoptosis in mouse: The prevention of curcumin. Toxicol. Appl. Pharmacol. 2014, 280, 305-313. [CrossRef]

88. Kotoh, K.; Enjoji, M.; Kohjima, M.; Nakamuta, M.; Takayanagi, R. A new parameter using serum lactate dehydrogenase and alanine aminotransferase level is useful for predicting the prognosis of patients at an early stage of acute liver injury: A retrospective study. Comp. Hepatol. 2008, 7, 6. [CrossRef]

89. Poudel, B.; Nepali, S.; Xin, M.; Ki, H.; Kim, D.; Lee, Y. Flavonoids from Triticum aestivum inhibit adipogenesis in 3T3-L1 cells by upregulating the insig pathway. Mol. Med. Rep. 2015, 12, 3139-3145. [CrossRef] [PubMed]

90. Lee, S.H.; Lee, Y.M.; Le, H.S.; Kim, D.K. Anti-oxidative and anti-hyperglycemia effects of Triticum aestivum wheat sprout water extracts on the streptozotocin-induced diabetic mice. Korean J. Pharmacogn. 2009, 40, 408-414.

91. Guecheva, T.; Henriques, J.A.; Erdtmann, B. Genotoxic effects of copper sulphate in freshwater planarian in vivo, studied with the single-cell gel test (comet assay). Mutat. Res. Genet. Toxicol. Environ. Mutagen. 2001, 497, 19-27. [CrossRef]

92. Bolognesi, C.; Landini, E.; Roggieri, P.; Fabbri, R.; Viarengo, A. Genotoxicity biomarkers in the assessment of heavy metal effects in mussels: Experimental studies. Environ. Mol. Mutagen. 1999, 33, 287-292. [CrossRef] 
93. Aschner, M.; Guilarte, T.R.; Schneider, J.S.; Zheng, W. Manganese: Recent advances in understanding its transport and neurotoxicity. Toxicol. Appl. Pharmacol. 2007, 221, 131-147. [CrossRef] [PubMed]

94. Jiao, J.; Qi, Y.M.; Fu, J.L.; Zhou, Z.C. Manganese-induced single strand breaks of mitochondrial DNA in vitro and in vivo. Environ. Toxicol. Pharmacol. 2008, 26, 123-127. [CrossRef]

95. Huang, C.C.; Chu, N.S.; Lu, C.S.; Wang, J.D.; Tsai, J.L.; Tzeng, J.L.; Wolters, E.C.; Calne, D.B. Chronic manganese intoxication. Arch. Neurol. 1989, 46, 1104-1106. [CrossRef]

96. Lee, S.H.; Jew, S.S.; Chang, P.S.; Hong, I.J.; Hwang, E.S.; Kim, K.S.; Kim, K.T. Free radical scavenging effect and antioxidant activities of barley leaves. Food Sci. Biotechnol. 2003, 12, 268-273.

97. Kulkami, S.D.; Tilak, J.C.; Acharya, R.; Rajurkar, N.S.; Devasagayam, T.P.; Reddy, A.V. Evaluation of the antioxidant activity of wheatgrass (Triticum aestivum, L.) as a function of growth under different conditions. Phytother. Res. 2006, 20, $218-227$.

98. Paulíčková, I.; Ehrenbergerová, J.; Fiedlerová, V.; Gabrovska, D.; Havlova, P.; Holasova, M.; Kopáček, J.; Ouhrabková, J.; Pinkrová, J.; Rysová, J.; et al. Evaluation of barley grass as a potential source of some nutritional substances. Czech J. Food Sci. 2007, 25, 65-72. [CrossRef]

99. Durairaj, V.; Hoda, M.; Shakya, G.; Babu, S.P.; Rajagopalan, R. Phytochemical screening and analysis of antioxidant properties of aqueous extract of wheatgrass. Asian Pac. J. Trop. Med. 2014, 7, S398-S404. [CrossRef]

100. Armendariz, A.D.; Gonzalez, M.; Loguinov, A.V.; Vulpe, C.D. Gene expression profiling in chronic copper overload reveals upregulation of Prnp and App. Physiol. Genom. 2004, 20, 45-54. [CrossRef] [PubMed]

101. Wu, J.; Basha, M.R.; Brock, B.; Cox, D.P.; Cardozo-Pelaez, F.; McPherson, C.A.; Harry, J.; Rice, D.C.; Maloney, B.; Chen, D.; et al. Alzheimer's disease (AD)-like pathology in aged monkeys after infantile exposure to environmental metal lead (Pb): Evidence for a developmental origin and environmental link for AD. J. Neurosci. 2008, 28, 3-9. [CrossRef] [PubMed]

102. Lee, H.J.; Park, M.K.; Seo, Y.R. Pathogenic Mechanisms of Heavy Metal Induced-Alzheimer's Disease. Toxicol. Environ. Health Sci. 2018, 10, 1-10. [CrossRef]

103. Ballatore, C.; Lee, V.M.; Trojanowski, J.Q. Tau-mediated neurodegeneration in Alzheimer's disease and related disorders. Nat. Rev. Neurosci. 2007, 8, 663-672. [CrossRef]

104. Chakravarthy, M.; Chen, S.; Wang, T.; Veedu, R.N. Development of novel chemically-modified nucleic acid molecules for efficient inhibition of human MAPT gene expression. Genes 2020, 11, 667. [CrossRef] [PubMed]

105. Caillet-Boudin, M.L.; Buée, L.; Sergeant, N.; Lefebvre, B. Regulation of human MAPT gene expression. Mol. Neurodegener. 2015, 10, 28. [CrossRef]

106. Alquezar, C.; Felix, J.B.; McCandlish, E.; Buckley, B.T.; Caparros-Lefebvre, D.; Karch, C.M.; Golbe, L.I.; Kao, A.W. Heavy metals contaminating the environment of a progressive supranuclear palsy cluster induce tau accumulation and cell death in cultured neurons. Sci. Rep. 2020, 10, 1-12. [CrossRef] [PubMed] 